\title{
BANKACILIK ZIMMETI SUÇU
}

\author{
Crime of Banking Embezzlement
}

\section{Onuralp ATAY*}

\begin{abstract}
Özet
Bankacılık zimmeti suçu 19/10/2005 tarih ve 5411 sayılı Bankacılık Kanunu'nun 160. maddesinde düzenlenmektedir. Bankacılık zimmeti suçunun faili ancak banka yönetim kurulu, başkan ve üyeleri ile diğer mensupları olabilir. Bankacılık işlemlerinin mülkiyet hakkına yönelik olması sebebiyle bankacılık zimmeti suçunun işlenmesiyle mülkiyet hakkının ihlâl edildiğini ve korunan hukuki değerin mülkiyet hakkı olduğunu belirtmek mümkündür. Ceza hukukuna göre suçun faili yalnızca gerçek kişi olabilir. $\mathrm{Bu}$ sebeple bankacılık zimmet suçunun faili de ancak gerçek kişi olabilecektir. Suçun konusu ise para veya para yerine geçen evrak veya senetleri veya diğer mallardır. Bankacılık Kanunu'nun 160/1 ve 160/3. maddelerinde iki ayrı suç düzenlenmektedir. İlk fikrada fiil, failin görevi nedeniyle zilyetliği kendisine devredilmiş olan veya koruma ve gözetimiyle yükümlü olduğu malı zimmete geçirmektedir. Üçüncü fikradaki fiil ise faaliyet izni kaldırılan veya Fon'a devredilen bir bankanın; hukuken veya fiilen yönetim ve denetimini elinde bulundurmuş olan gerçek kişi ortaklarının, kredi kuruluşunun kaynaklarını, kredi kuruluşunun emin bir şekilde çalışmasını tehlikeye düşürecek şekilde doğrudan veya dolaylı olarak kendilerinin veya başkalarının menfaatlerine kullandırmak olarak tanımlanmıştır.
\end{abstract}

Anahtar Kelimeler: bankacılık faaliyetleri, zimmet, varsayımsal zimmet, zilyetlik, kredi sözleşmeleri.

\begin{abstract}
Banking embezzlement is regulated in Article 160 of the Banking Law No. 5411 dated 19/10/2005. The perpetrator of the banking embezzlement crime can only be the bank's board of directors, chairman and members, and other members. It is possible to state that the right to property is violated by committing the crime of banking embezzlement, since the banking transactions are for the right of ownership, and the protected legal value is the right of ownership. According to criminal law, the perpetrator of the crime can only be a natural person. For this reason, the perpetrator of the banking embezzlement crime can only be a real person. The subject of the crime is money or money substitute documents or bills or other goods. Two separate offenses are regulated in the article 160 . The act in the first paragraph is embezzles the property
\end{abstract}

Bu makale Etik Kurul İznine tabi değildir.

* LL.M, Hâkim, Adalet Bakanlığı, İstanbul Üniversitesi Sosyal Bilimler Enstitüsü Kamu Hukuku Anabilim Dalı Doktora Öğrencisi, onuralp.atay@ogr.iu.edu.tr, http://orcid. org/0000-0001-8434-6057 
IIIIIIIIII

whose possession has been transferred to him due to his duty or which he is obliged to protect and supervise. The act in the third paragraph is the real person shareholders have held the control the management and supervision of a bank whose permission for banking transactions has been revoked or has been transferred to the SDİF, are proven to have used the credit instution's resources directly or indirectly in their own interests or in the third persons, their such acts shall be considered embezzlement.

Keywords: bank activities, embezzlement, hypothetical embezzlement, possession, loan agreements.

\section{GíRIŞ}

Bankacılık faaliyetlerinin ülke ekonomisine olan etkilerinin boyutu düşünüldügünde bankacılığa ilişkin özel düzenlemelerin gerekliliği tartışmasızdır. Banka kaynaklarının kötüye kullanılmasının toplumsal etkileri de göz önüne alındığında bankacılık suçlarına özel bir önem atfedilmiştir. Kanun koyucu bu nedenle bankacılık zimmetini 5411 sayılı Bankacilık Kanunu'nda ayrı bir düzenlemeyle ele almıştır.

Çalışmamızda da Bankacılık Kanunu'nda düzenlenen zimmet suçu ele alınmıştır. Bankacılık zimmeti suçunun Türk Ceza Kanunu'nda yer alan zimmet suçuyla büyük benzerlikler göstermesi sebebiyle zaman zaman Türk Ceza Kanunu'nda düzenlenen zimmet suçuna ilişkin değerlendirmelere de yer verilecektir. Çalışmamız üç bölümden oluşmaktadır. İlk bölümde genel olarak bankanın tanımı ve gerçekleştirdikleri faaliyetlerin niteliği üzerinde durulmaktadır. Çalışmamızın ikinci bölümünde bankacılık zimmeti suçu, korunan hukuki değer, suçun konusu, fail, fiil, manevi unsur bakımından izah edilmeye çalışılacaktır. Bu bağlamda varsayımsal zimmet suçunun niteliği, suçun oluşma şartları ve suça ilişkin tartışmalı hususlar aktarılacaktır. Çalışmamızın üçüncü ve son bölümünde ise suçun özel görünüş şekilleri, yaptırım ve etkin pişmanlık hükümleriyle bankacılık zimmetinin soruşturma ve kovuşturmasına ilişkin özel hükümlere değinilecektir.

\section{BANKACILIK FAALIYYTLERİ VE BANKACILIKZIMMETİ}

\section{A. Banka Kavramı}

Bankaların tüm özelliklerini kapsayan bir tanım yapılması zordur ${ }^{1}$. Bankaya ilişkin sabit bir tanım yapılamamasının nedeni, gelişen teknoloji ve ekonomi alanında bankaların faaliyet alanının çeşitlenip genişlemesidir. Türk Ticaret Kanunu'nun 815. maddesinde bankanın tanımına ilişkin "Bu Kısımda geçen "banka”dan amaç, Bankacılık Kanunu'na tabi olan kuruluşlardır." denilmektedir. Mevzuatımızda TTK'daki tanımın dışında banka ve bankacılık

1 Selman Dursun, Ekonomik Suçlar ve Bankacılık Suçları Bağlamında Bankacılık Düzenine Karşı İşlenen Suçlar, (2006), s.117. 
faaliyetlerine yönelik detaylı açıklamalara 4389 sayılı mülga Bankalar Kanunu'nda yer verilmekle birlikte ilgili Kanun'da da bankanın tanımına ilişkin bir açıklama getirilmemişti. 5411 sayılı Bankacılık Kanunu ile birlikte 2000'li yıllarda bankacılık krizinin ortaya çıkmasıyla bankacılık hukuku tekrar ele alınmıştır. İlgili Kanun ile bankacılık sisteminin daha sıkı şekilde denetlenmesi amaçlanmış ve sistemin işleyişine ilişkin hukuki ve cezai düzenlemeler yapılmışıır2. 5411 sayılı Bankacılık Kanunu'nun "Tanımlar ve kısaltmalar" başliklı 3. maddesinde "...Mevduat bankası: Bu Kanuna göre kendi nam ve hesabina mevduat kabul etmek ve kredi kullandirmak esas olmak üzere faaliyet gösteren kuruluşlar ile yurt dışında kurulu bu nitelikteki kuruluşların Türkiye'deki şubelerini..." şeklinde tanımlansa da ilgili düzenlemeyle de bankaya ilişkin kapsamlı bir tanımlama getirildiği söylenemez zira mevduat bankasının yanında katılım bankası, kalkınma ve yatırım bankası gibi farklı türlerde bankanın kurulması da mümkündür. Yine de düzenlemeyle Bankacılık Kanunu'na göre kurulmuş ve adında banka olan kuruluşlar banka sayılarak şekli bir tanım yapılmıştır ${ }^{3}$.

Doktrinde ise bankaya ilişkin farklı tanımlara yer verilmiştir. Bir tanıma göre banka, mevduat kabul eden, özel cari ve katılım hesapları yoluyla fon toplayan veya fon kabul eden ve topladiklarını kredi olarak kullandiran ve özel yasaları ile kendilerine verilen görevleri yerine getiren ekonomik kuruluş olarak tanımlanmaktadır ${ }^{4}$. Diğer bir tanıma göre banka, bir çatı kavram olarak; sahibi, faaliyet konuları, kuruluşu, faaliyete geçmesi, yönetimi, iç denetimi, öz kaynakları, özel kanununda öngörülmüş bulunan, kamu hukuku nitelikli düzen kuralları ile düzenlenen işletmenin adı şeklinde ifade edilmiştir ${ }^{5}$.

\section{B. 5411 Sayılı Kanun Bağlamında Bankaların Kuruluşu ve Faaliyetleri}

Tarihsel süreçte bankalar, topladıkları mevduatı, müşterilerine kredi vermek suretiyle ekonomiye kazandıran bir işlev görmüşlerdir ${ }^{6}$. Günümüzde ise bankaların iki temel fonksiyonu: mevduat veya benzeri paraları kabul etmek ve bunları kredi olarak kullandırmaktır . Yürürlükten kalkan 4389 sayılı

\footnotetext{
Yasemin Baba, "5411 Sayılı Bankacılık Kanununda Düzenlenen Zimmet Suçu Bağlamında Etkin Pişmanlık Uygulaması” (2012) ( S.9), Türkiye Adalet Akademisi Dergisi 253, s.253.

3 Ahmet Mücahit Selçuk, "5411 Sayılı Bankacılık Kanununda Düzenlenen Zimmet Suçları" İstanbul Üniversitesi Sosyal Bilimler Enstitüsü, Yayımlanmamış Yüksek Lisans Tezi, İstanbul, s.7.

4 Süheyl Donay, Bankacılık Ceza Hukuku, (2007), s.11.

5 Ünal Tekinalp, Ünal Tekinalp'in Banka Hukuku'nun Esasları, (Yeniden Yazılmış 2.Baskı, 2009), s.9.

6 Çağatay Uygun, “Bankacılık Kanunu'nun 160'ıncı Maddesinde ve Türk Ceza Kanunu'nun 247'nci Maddelerinde Yer Alan Zimmet Suçu”, Yeditepe Üniversitesi Sosyal Bilimler Enstitüsü, Yayınlanmamış Yüksek Lisans Tezi, İstanbul, s.22.

7 Göksel Tiryaki, "Ekonomik Suçlar, Bankacılık Suçları ve Bu Tür Suçlarla Mücadele Stratejisi”, (2004) (S.34) Active Bankac1lık ve Finans Dergisi 56, s.56.
} 
IIIIIIIIII

mülga Bankalar Kanunu'nda banka faaliyetlerinin neler olduğu belirsizdi. $\mathrm{Bu}$ durum bazı faaliyetlerin bankacılık faaliyeti olup olmadığı konusunda tereddüte neden olmaktaydı ${ }^{8}$. Tereddütleri ortadan kaldırmak için bankacılık faaliyetlerinin neler olduğu ilk kez 5411 sayılı Bankacılık Kanunu'nda düzenlenmiştir. Bankacılık Kanunu'nun 4. maddesinde bankaların faaliyet alanları tek tek sayılmıştır. Bunun nedeni, ülkemizde yaşanan ekonomik krizler neticesinde bankaların sıkı bir mali ve hukuki denetim altına alınması amacıdır 9 . İlgili maddenin 1.fikrasının (v) bendinde Kurulca belirlenecek diğer faaliyetlerin de bankacılık faaliyeti sayılacağ faaliyetlerinin teknolojiyle birlikte çeşitlenmesi, yeni ekonomik ihtiyaçların ortaya çıkması gibi durumlarda bankacılık mevzuatının piyasa koşullarına kolaylıkla uyum sağlayabilmesi için Bankacılık Düzenleme ve Denetleme Kurulu'nun belirleyeceği faaliyetlerin de bankacıllk faaliyeti olarak kabul edilebileceği kararlaştırılmıştır. Mevduat kabulü, katılım fonu kabulü, nakdî, gayrinakdî her cins ve surette kredi verme işlemleri, nakdî ve kaydî ödeme ve fon transferi işlemleri, muhabir bankacılık veya çek hesaplarının kullanılması dâhil her türlü ödeme ve tahsilat işlemleri, çek ve diğer kambiyo senetlerinin iştirası işlemleri, saklama hizmetleri, kredi kartları, banka kartları ve seyahat çekleri gibi ödeme vasıtalarının ihracı ve bunlarla ilgili faaliyetlerin yürütülmesi işlemleri, efektif dâhil kambiyo işlemleri; para piyasası araçlarının alım ve satımı; kıymetli maden ve taşların alımı, satımı veya bunların emanete alınması işlemleri gibi işlemler bankacılık faaliyetleri arasında yer almaktadır.

Bankacılık işlemlerinin temelinde müşteri ile banka arasında kurulan güven ilişkisi bulunmaktadır ${ }^{10}$. Bankacılık faaliyetlerinden en yaygını kredi sözleşmeleridir. Kredi, bir bankanın bankacılık kurallarında belirlenen şekilde gerçek veya tüzel kişilere teminat karşıllğı para vermek, kefalet garantisi sağlamak gibi işlemler olarak tanımlanabilir. Kredi sözleşmesi ile banka, müşterisine öngörülen limit kadar krediyi hazır bulundurma ve talep halinde kullandırma, kredi alan ise ana borcu, faizi ve komisyonları vade tarihinde ödeme yükümlülüğü altındadır ${ }^{11}$. Zimmet suçu açısından kredi sözleşmelerinin önemine ilerleyen bölümde yer verilecektir ${ }^{12}$.

\section{SUÇUN KANUNI TANIMI}

Zimmet suçu esas olarak Türk Ceza Kanunu'nda düzenlenmesine rağmen 5411 sayılı Bankacılık Kanunu'nun 160. maddesinin ilk fikrasında “Görevi

\footnotetext{
$8 \quad$ Ali Sait Yüksel, Aslı Yüksel, Ülkü Yüksel, Bankacılık Hukuku ve İşletmesi, 6 vd.

9 Davut Gürses, Bankacılık Kanunu'na Göre Zimmet Suçu, (2.Bask1, 2009), s.5.

10 Ömrü Y1lmaz, Hakan Öncel, Ümit Şahin, Banka Zimmeti, (2018), s.8.

11 Adem Sözüer, "Yeni Bankacılık Kanununda Suçlar ve Yaptırımlar", (2005) (S.5) Hukuki Perspektifler Dergisi 166, s. 177-178.

12 Bkz: IV. Bölüm, D, 3.
} 
nedeniyle zilyetliği kendisine devredilmiş olan veya koruma ve gözetimiyle yükümlü olduğu para veya para yerine geçen evrak veya senetleri veya diğer malları kendisinin ya da başkasinın zimmetine geçiren banka yönetim kurulu başkan ve üyeleri ile diğer mensuplarl, altı yıldan oniki yıla kadar hapis ve beşbin güne kadar adli para cezası ile cezalandırllacakları gibi bankanın uğradı̆̆ zararı tazmine mahkûm edilirler." denilerek bankalar açısından özel bir hükümle düzenleme altına alınmıştır.

İkinci fikrada suçun hileli hareketle işlenmesi nitelikli bir hal olarak kabul edilmiştir. Buna göre "Suçun, zimmetin açığa çıkmamasını sağlamaya yönelik hileli davranışlarla işlenmesi hâlinde faile on iki ylldan az olmamak üzere hapis ve yirmibin güne kadar adli para cezası verilir; ancak, adli para cezasinın miktarı bankanın uğradı ̆̆ zararın üç katından az olamaz. Ayrıca meydana gelen zararın ödenmemesi hâlinde mahkemece re'sen ödettirilmesine hükmolunur."

İlgili maddenin üçüncü fikrasında "Faaliyet izni kaldırllan veya Fona devredilen bir bankanın; hukuken veya fiilen yönetim ve denetimini elinde bulundurmuş olan gerçek kişi ortaklarının, kredi kuruluşunun kaynaklarını, kredi kuruluşunun emin bir şekilde çalışmasını tehlikeye düşürecek şekilde doğrudan veya dolayl olarak kendilerinin veya başkalarının menfaatlerine kullandırmak suretiyle, kredi kuruluşunu her ne suretle olursa olsun zarara uğratmaları zimmet olarak kabul edilir..." denilmek suretiyle esasen zimmet tanımına uymayan bir eylem zimmet kabul edilerek yaptırım altına alınmaktadır.

Dördüncü fikrada bankacılık mevzuatı ile bankacılık usul ve prensiplerine uygun kredi kullandırma, bu kredileri temdit etme veya ek kredi kullandırma, taksitlendirme, teminata bağlama yahut sair yöntemlerle yeniden yapılandırma işlemlerinin zimmet suçunu oluşturmayacağı teyit edilmiştir.

Beşinci ve altıncı fikralarda soruşturma başlamadan önce ya da soruşturma ve kovuşturma aşamasında etkin pişmanlık gösterilmesi halinde verilecek cezada farklı oranlarda indirim yapılacağı belirtildikten sonra yedinci fikrada zimmet suçunun konusunu oluşturan malın değerinin az olması halinde verilecek cezadan üçte birden yarıya kadar indirim yapılacağı kabul edilmiştir.

Türk Ceza Kanunu'nda zimmet suçu 247. maddede düzenlenmektedir. İlgili madde uyarınca; "Görevi nedeniyle zilyetliği kendisine devredilmis olan veya koruma ve gözetimiyle yükümlü olduğu malı kendisinin veya başkasının zimmetine geçiren kamu görevlisi, beş ylldan on iki yıla kadar hapis cezast ile cezalandırllır.". Özgü bir suç olan zimmet suçunda fail ancak kamu görevlisi olabilmektedir. Zimmet suçunda fiil zimmete geçirmektir. Zimmete geçirmek, suç konusu mal üzerinde malikmiş gibi tasarrufta bulunmayı ifade eder. Madde gerekçesinde de belirtildiği üzere, zimmet suçunun oluşabilmesi için, suça konu malın kamu görevlisinin şahsının veya bir başkasının zimmetine geçirilmiş 
IIIIIIIIII

olması arasında fark bulunmamaktadır ${ }^{13}$. Zimmet suçunda kamu görevlisi olan fail, kamu idaresinin görevi sebebiyle zilyet olduğu malı zimmetine geçirerek hem kamuyu zarara uğratmakta hem de kamu idaresine duyulan güveni sarsmaktadır ${ }^{14}$. Bu sebeple zimmet suçunun mağduru da kamu idaresidir.

Bankacılık zimmeti Türk Ceza Kanunu'nun 247. maddesinde düzenlenen zimmet suçuyla benzer unsurları taşımasına rağmen iki suç failler açısından farklılaşmaktadır. Bankacılık zimmeti ile Türk Ceza Kanunu'nda yer alan zimmet suçunun maddi unsurlarının benzerlik göstermesi nedeniyle Türk Ceza Kanunu'nda yer alan zimmet suçuna ilişkin yapılan değerlendirmeler bankacılık zimmeti suçu açısından da önemlidir. Anayasa Mahkemesi de banka mensupları tarafından işlenen zimmet suçunun aslında Türk Ceza Kanunu'ndaki zimmet suçunun aynısı olduğunu; ancak bir güven kurumu niteliğinde olan bankaların mensuplarının zimmet fiillerinin kamu düzenine ve ekonomiye etkilerini düşünerek, ceza siyasetinin bir gereği olarak daha fazla ceza öngörülmek suretiyle Bankacılık Kanunu'nda düzenlendiğini belirtmiştir ${ }^{15}$. Türk Ceza Kanunu'nda uzun zamandır suç olarak tanımlanmış bir fiilin, özel kanunlara hüküm eklenmek suretiyle tekrar edilmesi kanun tekniği bakımından eleştiriye açık bir husustur. Bu bağlamda Kanun koyucu'nun bankacılık faaliyetleri aracılığıyla işlenen suçlara daha ağır bir yaptırım uygulamak istemesi halinde bunu Türk Ceza Kanunu'nda yer alan suça yeni bir fikra ile daha ağır cezayı gerektiren nitelikli hal ekleyerek yapmasının daha doğru olacağ ifade edilmektedir ${ }^{16}$.

\section{KORUNAN HUKUKİ DEĞER}

Ceza hukuku haksız ve hukuka aykırı gördüğü fiilleri suç olarak belirleyerek toplum bakımından önemli görülen bazı değerleri koruma altına almaktadır ${ }^{17}$. Esasen yaptırım altına alınan her suçta kamu düzeninin korunması hukuki değer olarak belirlenebilir ancak kamu düzeninin yanında bazı suç tiplerinin somut olarak daha belirgin ve özel nitelikteki hukuki değerleri konu edindiği söylenebilecektir. Bankacılık zimmet suçunun hangi hukuki değeri koruduğu konusunda doktrinde görüş birliği bulunmamaktadır. Bankacılık zimmetinin Türk Ceza Kanunu'nda yer alan zimmet suçunun özel bir hali olduğu göz önüne alındığında zimmet suçuyla korunan hukuki değere ilişkin açıklamalara değinmek gerekir. Türk Ceza Kanunu'nda düzenlenen zimmet suçunda

13 Yargitay Ceza Genel Kurulu, 5-557/214, 27/03/2018, <www.uyap.gov.tr $>$ (Erişim Tarihi:18/12/2020)

14 Nur Centel, “Zimmet Suçu (TCK 247)” (2019) 21 (Özel Sayı) Dokuz Eylül Üniversitesi Hukuk Fakültesi Dergisi, Prof. Dr. Durmuş TEZCAN'a Armağan 2779, s. 2785.

15 Anayasa Mahkemesi, 103/199, 25.12.2014, https://normkararlarbilgibankasi.anayasa.gov. tr/ (Erişim Tarihi: 27/06/2021)

16 Sözüer, s.167.

17 Selçuk, s.82. 
korunan hukuki değer, devlet görevlileri ile kamu idaresine karşı duyulan güvenin korunması ve kamu görevlilerinin devlete karşı sahip oldukları sadakat yükümlülüğüne uygun davranılmasının sağlanmasıdır ${ }^{18}$. Kamu görevlilerinin görevleri dolayısıyla kendilerine emanet edilen malvarlığını koruma, gözetme ve malvarlığ 1 üzerinde tevdi amacına uygun biçimde tasarrufta bulunma yükümlülükleri mevcuttur ${ }^{19}$.

Bankacılık zimmeti özelinde korunan hukuki değer ise ekonomik düzenin işleyişi yanında mülkiyet hakkı ve güven ilişkisidir ${ }^{20}$. Bankaların sosyal ve ekonomik alanda güven ve istikrarın sağlanmasında, ekonomik gidişatın ülke genelinde güven esasına göre yürütülmesinde büyük bir yeri ve önemi olduğu belirtilerek bankacılık zimmeti suçlarında para ve para hükmündeki malvarlıklarının halkın güven duygusunu sarsmadan muhafaza edilmesini ve duyulan güven duygusunun sarsılmasını önlemeyi amaçladığı da savunulmaktadır ${ }^{21}$. Bir görüşe göre ise bankacılık zimmeti suçunda fail, zimmet suçundaki gibi kamu görevlisi olmayan, özel bir teşebbüste çalışan ve kamu gücü kullanmayan bir kişi olduğu için bankacılık faaliyetleri, mülkiyet hakkının özel bir görünüşü niteliktedir. Bankacılık faaliyetlerinin ülke ekonomisi için önem arz eden yapısının bu hususu değiştirmeyeceği, her ne kadar zimmet suçuyla aynı ismi taşısa da bankacılık zimmeti suçunda korunan hukuki değerin farklı olduğu belirtilmektedir ${ }^{22}$. Anayasa Mahkemesi ise bankacılık zimmet suçunda korunan hukuki değere ilişkin bir kararında, bankaların bir güven kurumu niteliğinde olduğunu belirterek, bu suçla birlikte finans kuruluşlarına olan güvenin ve bu kurumların ekonomik hayatın güvenilirliği ve işleyişindeki rolüne vurgu yapmıştır ${ }^{23}$.

21

23

Sözüer, s. 175.

"...Finansal piyasalara ve finansal kurumlara güvenin sağlanmas,, kamu düzeni güvenliğinin temininden ayr değerlendirilebilecek bir husus olmayıp, finansal piyasalara ve kurumlara güvenin sağlanması da kamu düzeni ve güvenliğinin săglanmasının önemli bir unsurudur. Bu bağlamda, yasa koyucun bir güven kurumu olan bankaların güvenilirliğini sağlamak ve bu güvenilirliği devam ettirmek amactyla, eylemin toplumda ve ekonomik hayatta yaratabileceği etkiler ile işlenme oranında ortaya çıkabilecek artışların kamu düzeni ve güvenliğine etkisini de dikkate alarak, ceza siyasetinin bir gereği olarak takdir yetkisi kapsamında banka mensupları tarafindan işlenen zimmet suçunu, Türk Ceza Kanunu'nda düzenlemek yerine Bankacılık Kanunu'nda özel bir düzenleme yaparak daha ă̆ır bir yaptırıma tâbi tutmasında hukuk devleti ilkesine aykırılık bulunmamaktadır..." Bkz: Anayasa Mahkemesi, 2010/116, 2011/118, 7.7.2011, <https:/normkararlarbilgibankasi. anayasa.gov.tr/ > (Erişim Tarihi: 19/12/2020). 
IIIIIIIIIII-

Belirtilen görüşler 1şığında bankacılık zimmeti suçunda birden fazla hukuki değerin korunduğu söylenebilecektir. Bankacılık zimmeti suçuyla bir yandan bankanın mülkiyet hakkı, diğer yandan bankacılık sisteminin güven ve istikrar içerisinde etkin, düzenli ve verimli şekilde çalıştığına ilişkin kamusal inancın korunması söz konusudur ${ }^{24}$. Gerçekten, bankacılık faaliyetlerinin ülke ekonomisi bakımından önemi, bankacılık faaliyetleri ile ilgili işlenen suçların hem ülke ekonomisi hem de toplumsal etkileri düşünüldügünde bankacılık zimmeti suçuyla Türk Ceza Kanunu'nda yer alan zimmet suçundan farklı olarak özel bir düzenleme yapılmasının ekonomik düzenin ve işleyişinin korunması amacını güttüğü söylenebilir. Bunun yanında banka personellerinin kamu gücünü kullanan bir kamu personeli olmaması ve banka ile müşteri arasında kurulan özel hukuk ilişkisi de düşünüldüğünde, bankacılık zimmet suçuyla taraflar arasındaki güven ilişkisinin ve mülkiyet hakkının korunduğu da ifade edilebilecektir.

\section{SUÇUN MADDİ UNSURLARI}

\section{A. Fail}

Bankacılık zimmeti suçu da tıpkı Türk Ceza Kanunu'ndaki zimmet suçu gibi özgü suçlardandır. Özgü suçlarda suçun faili herkes değil, yalnızca belirli sıfata sahip kişiler olabilmektedir ${ }^{25}$. Ayrıca suçun faili yalnızca gerçek kişi olabilmektedir. Suç bir tüzel kişilik faaliyeti çerçevesinde işlenmekteyse tüzel kişilikteki fiili işleyen sorumlu gerçek kişi tespit edilmelidir ${ }^{26}$.

\section{Bankacılık Kanunu'nun 160/1. Maddesindeki Fiil Bakımından Fail}

5411 sayıl1 Bankacılık Kanunu'nun 160/1. maddesinde "Görevi nedeniyle zilyetliği kendisine devredilmiş olan veya koruma ve gözetimiyle yükümlü olduğu para veya para yerine geçen evrak veya senetleri veya diğer mallar kendisinin ya da başkasının zimmetine geçiren banka yönetim kurulu başkan ve üyeleri ile diğer mensupları..." suçun faili olarak belirlenmiştir. Görüldüğü üzere bankacılık zimmeti suçu ancak Kanun'da sayılan bankada görevli banka mensubu tarafından işlenebilmektedir. Banka yönetim kurulu başkan ve üyelerinin kimler olduğunun tespitini yapma konusunda tereddüt bulunmamaktadır. Ancak "diğer mensuplar" kavramına kimlerin dâhil olduğu tereddüt yaratabilir. Banka mensubundan anlaşılması gereken, bankanın her kademedeki mensubudur. Bu çerçevede suçun kredi kullandırılmak suretiyle işlenmesi halinde, krediilişkisini tevdi amacı dışında oluşturanbankamensupları, duruma göre yönetim kurulu üyeleri, genel müdür ya da yardımcıları, kredi

24 Hasan Tahsin Gökcan, Güveni Kötüye Kullanma, Zimmet, Banka Zimmeti, İrtikap, Rüşvet Suçları ve Kamu İdaresi'ne Karşı İşlenen Suçlar, (2008), s.439.

25 Gürses, s.117.

26 Muhammet Erişen, "Bankacılık Zimmeti”, (2011) (S.83), Sayıştay Dergisi 97, s.101. 
komitesi üyeleri, bölge ve şube müdürleri fail olabileceklerdir ${ }^{27}$. Bankadaki etki ve yetki alanları göz önüne alındığında genel müdür ile sıradan bir banka personelinin aynı madde hükmüne göre cezalandırılmasının eşitlik ilkesine aykırı olduğu iddiasını Anayasa Mahkemesi, “...kredi kuruluşunun Yönetim kurulu başkan ve üyeleri dışında kalan diğer banka mensuplarının işleyeceğ $i$ zimmet suçunun da finansal piyasalar ve finansal kurumlara duyulan güvene verebileceği zarar göz önüne alındı̆̆ında, aynı yükümlülüklere tâbi olan banka yönetim kurulu başkan ve üyeleri ile diğer banka mensupları arasında ayırım yapılmaksızın ayn yaptırıma tâbi tutulmasında eşitlik ilkesine aykırı bir yön bulunmamaktadır..." gerekçesiyle reddetmiştir ${ }^{28}$.

Suçun faili bakımından, failin banka ile bir sözleşme ilişkisinin bulunması, bu ilişkinin de yöneticilikten ya da mensupluktan kaynaklanması gereklidir29. Bunun yanında failin görev tanımının bankacılık faaliyetiyle de ilgisinin bulunması gereklidir ${ }^{30}$. Banka güvenlik görevlisinin diğer mensup kavramına girip girmediği ise tartışmalıdır. Güvenlik görevlisi ile banka arasında doğrudan hizmet sözleşmesinin varlığ bankanın mensubu sayılacağını, ancak güvenlik hizmetinin dışarıdan hizmet satın alma yoluyla yapılması halinde güvenlik görevlisinin zimmet suçunun faili olamayacağını ileri süren bir görüş mevcuttur ${ }^{31}$. Yargitay ise bankada kadrolu güvenlik görevlilerinin bankacılık zimmeti suçunun faili olabileceğini kabul etmektedir ${ }^{32}$.

\section{Bankacılık Kanunu'nun 160/3. Maddesindeki Fiil Bakımından Fail}

5411 sayıl1 Bankacilık Kanunu'nun 160/3. maddesinde "Faaliyet izni kaldirllan veya Fona devredilen bir bankanın; hukuken veya fiilen yönetim ve denetimini elinde bulundurmuş olan gerçek kişi ortaklarının, kredi

27 Fatih Selami Mahmutoğlu, Ekonomik Suçlar Bağlamında Kredi Hukukundan Kaynaklanan Suç ve İdari Suçlar, s.231.

28 Anayasa Mahkemesi, 2010/116, 2011/118, 21/10/2011, <https://normkararlarbilgibankasi. anayasa.gov.tr/ > (Erişim Tarihi: 19/12/2020)

29 Donay, s.110.

30 “...Zimmet suçunun 5237 sayılı TCK.nun 40/2 maddesinde belirtilen özgü suçlardan olduğu ve anılan maddedeki düzenlemeye göre "Özgü suçlarda, ancak özel faillik niteliğini taşıyan kişi fail olabilir, "düzenlemesi karşısında, dairemizin yerleşik kararlarında da bahsedildiği üzere genel müdür yardımcısının makam şoförü olan sanık...'nın görev tanımının bankacılık faaliyetleri ile ilgili olmadığ görevinin bankacılık faaliyetleri ile ilgili olmadığı gibi bu konuda yetkilendirildiğine dair resmi bir belge bulunmadığı, bu haliyle suçun faili olamayacağı; diğer sanık ...)un da banka çalışanı olmayıp taşeron firma elemanı olduğu, sanıkların bankacılık işlemleri ve banka parasını korumak gibi görevlerinin olmadığı cihetle; suçun sübutu halinde eylemin emniyeti suistimal suçunu oluşturacağı..." Yargitay 7.Ceza Dairesi, 17090/3625 26/04/2017, < www. uyap.gov.tr.> (Erişim Tarihi: 19/12/2020).

31 Gürses, s.24.

32 Yargitay 7.Ceza Dairesi, 2010/13998, 2012/3094, 03/12/2012,< www.uyap.gov.tr. > (Erişim Tarihi: 19/12/2020). 
IIIIIIIIIII-

kuruluşunun kaynaklarını, kredi kuruluşunun emin bir şekilde çalışmasını tehlikeye düşürecek şekilde doğrudan veya dolayl olarak kendilerinin veya başkalarının menfaatlerine kullandirmak suretiyle, kredi kuruluşunu her ne suretle olursa olsun zarara uğratmalart zimmet olarak kabul edilir..." denilmektedir. Maddeden de anlaşılacağı üzere esasen zimmet tanımına uymamakla birlikte kredi kuruluşunun kaynaklarını, kredi kuruluşunun emin bir şekilde çalışmasını tehlikeye düşürecek şekilde kullanma fiili, zimmet kabul edilerek cezalandırılmaktadır. Bankacılık Kanunu'nun 160. maddesinin 3.fikrasında 1.fikradan bağımsız olarak ayrı bir suç düzenlenmektedir. Kanun tekniği açısından bunun doğru bir husus olmadığını belirtmek gerekir. Bankacılık Kanunu'nun 160/3. maddesine ilişkin detaylı açıklama çalışmanın ilerleyen bölümlerinde yapılacağından burada yalnızca suçun failinin tespitiyle yetinilecektir ${ }^{33}$. Suçun faili, faaliyet izni kaldırılan veya Fon'a devredilen bankanın fiilen veya hukuken denetimini elinde bulunduran gerçek kişi ortaklardır. Bankanın fiilen veya hukuken denetimini elinde bulundurmayan banka personeli suçun faili olamayacaktır ${ }^{34}$. Kanun'da belirtildiği gibi gerçek kişi ortağın sadece yönetim yetkisinin veya denetim yetkisinin olması yeterli değildir. Yönetim ve denetim yetkisinin birlikte bulunması gereklidir ${ }^{35}$. Bankanın ortak olmayan yönetim kurulu üyeleri ve diğer mensupları bu fikra kapsamında fail olamayacaktır, eğer suça iştirak koşulları varsa fail olarak değil suça yardım eden olarak cezalandırılacaktır ${ }^{36}$.

\section{B. Suçun Mağduru}

Suçun mağduru ile suçtan zarar gören kavramı karıştırılsa da zarar gören, mağdurdan farklı bir kavramı karşılamaktadır. Mağdur, failin suç teşkil eden hareketinden doğrudan etkilenen kişi iken; suçtan zarar gören doğrudan veya dolaylı olarak etkilenebilir. Mağdur suçun maddi unsuruna muhatap olan ve bu nedenle suçla korunan hukuki yararı zedelenen kişidir $^{37}$. Gerçek kişiler suçun mağduru olabilirken tüzel kişiler ancak suçtan zarar gören olabilir ${ }^{38}$. Bir görüşe göre bankacılık zimmeti suçunun mağduru banka tüzel kişiliğidir ${ }^{39}$. Suç konusu malın maliki banka ise suçun mağdurunun da banka olduğunu, suça konu mal bankaya ait olmamakla birlikte herhangi bir bankacılık faaliyeti

\footnotetext{
33 Bkz: IV. Bölüm, D, 3.

34 Sözüer, s.175.

35 Y1lmaz, Öncel, Şahin, s.55.

36 Sözüer, s.185.

37 Hakan Hakeri, Ceza Hukuku Genel Hükümler, (24.Bask1, 2021), s.117.

38 Mehmet Emin Artuk, Ahmet Gökçen, Ahmet Caner Yenidünya, Ceza Hukuku Özel Hükümler, (11.Bask1, 2011), s.762; Sözüer, s.179.

39 Devrim Güngör, "5411 Sayılı Bankacılık Kanununda Zimmet Suçu” (2009) (S.4), Ankara Barosu Dergisi 23, s.23; Erişen, s.114.
} 
kapsamında bankanın uhdesinde bulunuyorsa bu durumda suçun mağdurunun malın sahibi, suçtan zarar görenin ise banka tüzel kişiliği olacağını ifade eden bir görüş de mevcuttur ${ }^{40}$. Yargı kararlarında ise farklı değerlendirmeler yapılmıştır. Yargıtay bazı kararlarında bankanın suçun mağduru ${ }^{41}$ olduğunu kabul ederken bazı kararlarında suçtan zarar gören ${ }^{42}$ olduğuna hükmetmiştir. Bize göre bankacılık zimmeti suçlarında suç konusunu oluşturan şeyin banka vasıtasıyla zimmete geçirildiği gözetildiğinde bankanın güvenilirliğinin ve itibarının zedelendiği açıktır. Bir tüzel kişinin suçun mağduru olamayacağ da göz önüne alındığında bankacılık zimmeti suçlarında banka suçtan dolaylı olarak etkilenen konumundadır. Bu sebeple bankanın ancak suçtan zarar gören olabileceği kabul edilmelidir.

\section{Suçun Konusu}

5411 say11 Kanun'un 160. maddesinde yer alan suçun konusunu para veya para yerine geçen evrak veya senetleri veya diğer mallar oluşturmaktadır. Doktrinde para, evrak ve senetlerin esasında bir mal olduğu ve Kanun'da suç konularının tek tek sayılması yerine mal ibaresinin yeterli olacağı ifade edilmektedir ${ }^{43}$. Para yerine geçen evrak ve senetler Türk Ceza Kanunu'nun 198. maddesinde sayılmaktadır. Devlet tarafından ihraç edilip de hamiline yazılı bonolar, hisse senetleri, tahviller ve kuponlar, yetkili kurumlar tarafindan çıkarılmış olup da kanunen tedavül eden senetler, tahviller ve evrak ile milli ziynet altınları para hükmündedir. Bunların dışında kalan her türlü mal ise diğer mallar olarak kabul edilmelidir. Bankanın suç konusu olan malın maliki olması şart değildir. Görevi gereği zilyetliği kendisine devredilen her mal üzerinde zimmet suçu işlenebiliir ${ }^{44}$. Zilyetlik kavramına ilişkin Türk Ceza Kanunu'nda bir tanım yer almadığından kavramı tanımlamak için Türk Medeni Kanunu'na bakmak gereklidir. Türk Medeni Kanunu'nun 973/1. maddesinde “bir şey üzerinde fiili hâkimiyeti bulunan kimse onun zilyedidir." denilmektedir. Ceza hukuku açısından zilyetlik ise fiili veya hukuki bir durumu içermektedir ${ }^{45}$. Failin kendisine görevi gereği tevdi edilen şey üzerinde malikmiş gibi hareket ederek tasarrufta bulunması, fiilen malı uhdesine geçirmesi, yok etmesi veya başkasına devretmesi halinde suç oluşacaktır. Zilyetliğin devrine ilişkin olarak

40 İzzet Özgenç, Zimmet Suçu, s.129; Mehmet Emin Artuk, Ahmet Gökçen, Ahmet Caner Yenidünya, Ceza Hukuku Özel Hükümler 2011, s.795; Gürses, s.33; İsmail Malkoç, Yeni Türk Ceza Kanunu Uygulamasında Zimmet İrtikap Rüşvet Suçları, (2010), s.47.

41 Yargitay 7.Ceza Dairesi, 2010/5409, 2013/2083, 22/01/2013; Yargitay 7.Ceza Dairesi, 2009/6840, 2012/24951, 25/09/2012,< www.uyap.gov.tr. > (Erişim Tarihi: 19/12/2020)

42 Yargıtay 5.Ceza Dairesi, 13715/6077, 31/05/2012,< www.uyap.gov.tr. > (Erişim Tarihi: $19 / 12 / 2020)$

43 Sözüer, s.17; İzzet Özgenç, Zimmet Suçu, s.80.

44 İzzet Özgenç, Zimmet Suçu, s.80.

45 Yilmaz, Öncel, Şahin, s.23. 
IIIIIIIIII!

herhangi bir sınırlama belirtilmediği için zilyetliğin teslimli ya da teslimsiz şekilde devredilmesinin önemi yoktur ${ }^{46}$.

Bankacılık Kanunu'nun 160/3. maddesi açısından suçun konusu kredi kuruluşlarının kaynakları olarak belirlenmiştir. Esasen madde metninde hem banka hem de kredi kuruluşu ifadesine yer verilmesi belirsizlik yaratmaktadır. 5411 sayılı Kanun'un "Tanımlar ve Kısaltmalar" başl1klı 3. Maddesine göre kredi kuruluşları mevduat ve katılım bankalarını, banka kavramı ise mevduat, katılım ile kalkınma ve yatırım bankalarını ifade etmektedir. Görüldüğü gibi banka kavramı, kredi kuruluşu kavramına göre daha geniş bir kapsama sahiptir. Bir görüşe göre suçun kapsamının kredi kuruluşlarının kaynakları olarak algılanması gereklidir ${ }^{47}$. Diğer bir görüşe göre ise aynı fikra içinde hem banka hem kredi kuruluşu ibaresinin kullanılması maddi bir hatadan kaynaklanmaktadır. Bu sebeple suçun konusunu banka kaynakları olarak anlamak gerekir ${ }^{48}$. Bize göre suç ve cezaların kanuniliği ilkesi gereği ceza kanunlarının yorumunda suçun uygulanma kapsamını genişletecek şekilde yorum yapılmaması gerekmektedir. Kanun maddesinde hem banka hem kredi kuruluşu ibaresine yer verilmesinin tereddüt yarattığ şüphesizdir. Bu çelişki giderilene kadar suçun konusu kredi kuruluşunun kaynakları olarak kabul edilmelidir.

\section{Fiil}

\section{Genel Olarak}

Fiil, kişinin iradesiyle hâkim olduğu insan davranışıdır ${ }^{49}$. Ceza hukukunun konusu icrai ya da ihmali bir harekettir. ${ }^{50}$ Bankacılık Kanunu'nun 160. maddesinde iki farklı suçun düzenlendiğini belirtmiştik. Bu sebeple Bankacılık Kanunu'nun 160/1 ve 160/3. maddesindeki suçlar açısından fiillerin ayrı ayrı değerlendirilmesi gereklidir.

\section{Bankacılık Kanunu'nun 160/1. Maddesi Açısından Fiil}

\section{a. Zilyetliği Banka Mensuplarına Devredilen Malların Zimmete Geçirilmesi}

Bankacılık Kanunu'nun 160/1. maddesinde fiil ve suçun konusu "Görevi nedeniyle zilyetliği kendisine devredilmiş olan veya koruma ve gözetimiyle yükümlü olduğu para veya para yerine geçen evrak veya senetleri veya diğer malları kendisinin ya da başkasının zimmetine geçiren..." ş̧eklinde ifade

\footnotetext{
6 Gürses, s.53.

47 Gökcan, s.440.

48 Yılmaz, Öncel, Şahin, s.55.

49 İzzet Özgenç, Türk Ceza Hukuku Gazi Şerhi, (3.Bask1, 2006), s.153; Hakeri, s.128.

50 Hakeri, s.128.
} 
edilmiştir. Bu fikrada belirtilen suç açısından fiil zimmete geçirmek olarak ifade edilmektedir. Zimmete geçirmek, Türk Ceza Kanunu'nun 247. maddesinin gerekçesinde "suç konusu mal üzerinde, malikmiş gibi tasarrufta bulunmayı ifade eder. Bu tasarruflar, suç konusu şeyin mal edinilmesi, amacı dışında kullanılması, tüketilmesi şeklinde oluşabileceği gibi bir başkasına satılması, verilmesi şeklinde de gerçekleşebilir..." denilerek tanımlanmıştır ${ }^{51}$. Zimmet fiilinde fail, görevi dolayısıyla zilyetliği kendisine devredilmiş veya koruma ve gözetmekle yükümlü olduğu malı tahsis edildiği amaç dışında kendisi veya başkası için mal edinme kastıyla hareket etmelidir ${ }^{52}$.

\section{b. Koruma ve Gözetim Yükümlülüğü Bulunan Malların Zimmete Geçirilmesi}

Bankacılık Kanunu'nun 160/1. maddesinde zimmet suçunun ayrıca koruma ve gözetim yükümlülüğü bulunan mallar üstünde de işlenebileceği kabul edilmiştir. Bir görüşe göre koruma ve gözetim yükümlülügü bütün banka mensupları için geçerli değildir. Sadece bu konuda özel olarak yükümlendirilen banka personeli için geçerlidir ${ }^{53}$. Bu görüşün kabulü halinde koruma ve gözetim yükümlülüğü ancak banka iç denetçileri, teftiş kurulu personeli gibi mensuplar açısından söz konusu olacak ve sorumluluğun kapsamı daralacaktır ${ }^{54}$. Öte yandan banka personelinin özel bir yetkilendirme olmasa da banka değerleri üzerinde koruma ve gözetim yükümlülüğü bulunduğunu ileri süren bir görüş de mevcuttur ${ }^{55}$. Yargitay ise banka müdürü olan bir kişinin bankaya ait para ve diğer eşyaları koruma yükümlülüğü olduğunu kabul etmektedir ${ }^{56}$.

\section{Bankacılık Kanunu'nun 160/3. Maddesi Açısından Fiil}

Bankac1lık Kanunu'nun 160/3. maddesinde "Faaliyet izni kaldırlan veya Fon'a devredilen bir bankanın; hukuken veya fiilen yönetim ve denetimini elinde

515237 Sayılı TCK'nın 247. madde Gerekçesi, < www.tbmm.gov.tr.>(Erişim Tarihi: 20/12/2020)

52 Centel, s.2789.

53 İbrahim Murat Haznedar, Bankacılık Zimmeti Suçu, (2007), Legal Hukuk Dergisi 1169, s.1176.

54 Y1lmaz, Öncel, Şahin, s.30.

55 "Bankacılık faaliyeti niteliği gereği, banka personeli tarafından kollektif bir çaba ve yaygın bir entellektüel sermaye ve teknoloji kullanılarak gerçekleştirilen bir faaliyettir. Bankacılık zimmeti suçunun konusunu oluşturan değerlerin sadece özel olarak yükümlendirilen banka personeli tarafından korunması ve gözetime tâbi tutulması gerektiğini kabul etmek mümkün değildir. Aksi takdirde denetim ve gözetim yükümlülügüne ait yetkilerini kullanabilecek durumdaki banka personelinin herhangi bir nedenle bulunmadığı veya müdahale edemediği durumda bankaya ait değerlerin yeterince korunamaması riski doğar...” Bkz: Taner Gülșen, "Zimmet Suçu" Ankara Üniversitesi Sosyal Bilimler Enstitüsü, Yayımlanmamış Yüksek Lisans Tezi, Ankara, s.140.

56 Yargitay 7.Ceza Dairesi, 16842/14733, 02/07/2014, <www.uyap.gov.tr.> (Erişim Tarihi: 20/12/2020) 
IIIIIIIIIII-

bulundurmuş olan gerçek kişi ortaklarının, kredi kuruluşunun kaynaklarını, kredi kuruluşunun emin bir şekilde çalışmasinı tehlikeye düşürecek şekilde doğrudan veya dolaylı olarak kendilerinin veya başkalarının menfaatlerine kullandirmak suretiyle, kredi kuruluşunu her ne suretle olursa olsun zarara uğratmaları zimmet olarak kabul edilir..." denilmektedir. Suçun oluşabilmesi için öncelikle bankanın faaliyet izninin kaldırılması veya Fon'a devredilmesi gereklidir. Bu unsur aşağıda objektif cezalandırılabilme şartı olup olmadığı yönünden ayrıca tartışılacaktır ${ }^{57}$.

Öncelikle düzenlemenin ceza kanunu tekniğine uygun olmadığ belirtilmektedir ${ }^{58}$. Zimmet suçunda bir mal edinme söz konusuyken ilgili suçta doğrudan bir mal edinme söz konusu değildir. Bu sebeple suçun zimmet suçundan ayrı olarak "banka kaynaklarının istismarı" şeklinde adlandırılıp ayrı bir maddeyle düzenlenmesi ya da hizmet nedeniyle güveni kötüye kullanma suçu kapsamında değerlendirilmesi gerektiği ifade edilmiştir ${ }^{59}$. Suçta yer alan fiilin zimmet tanımına uymamakla birlikte zimmet kabul edilmesi sebebiyle doktrinde ilgili suç "varsayımsal zimmet suçu” olarak adlandırılmıştır60. Bunun yanında maddede yer alan "kredi kuruluşunun emin bir şekilde çalışmasını tehlikeye düşürecek şekilde" ifadesi belirsizlik yaratmaktadır. Bir görüşe göre kredi kuruluşunun emin şekilde çalışmasını tehlikeye düşürmek, söz konusu işlemlerin bankanın bünye sağlamlığını bozmasını ve bu durumun süreklilik kazanmasını ifade eder ${ }^{61}$. Yine de emin şekilde çalışma kavramının öznel ve soyut nitelikte olduğu ve her bankaya göre farkl1lık arz edebileceği unutulmamalıdır. Bu öznellik Kanun'da "kredi kuruluşunun emin bir şekilde çalışmasını tehlikeye düşürmek" ibaresinden ne anlaşılması gerektiğinin açıklanması ya da emin bir şekilde çalışmayı tehlikeye düşürecek hallerin örneklenmesi yoluyla giderilebilecektir.

İlgili düzenlemeyle banka yönetim kurulunda yer almayan ancak fiilen bankanın hâkimi olan ortağın bankayı kendisinin veya başkasının menfaatine olacak şekilde kullanması cezalandırılmak istenmiştir ${ }^{62}$. Esasen suçun oluşması için bankanın emin şekilde yönetilmemesi sonucu faaliyet izninin kaldırılması veya Fon'a devredilmesi halinde hâkim ortağın yaptığı kredi işlemlerinin sırf bankayı emin şekilde yönetmediği gerekçesiyle cezalandırılabilme ihtimali, bu krediyi tüm koşullara uygun olarak almış olsalar bile, kredi olarak kullanmış

57 Bkz: IV. Bölüm, D, 4.

58 Aynı yönde bkz: Sözüer, s.167; Güneş, Okuyucu Ergün, Bankacılık Kanunu'nda Düzenlenen Zimmet Benzeri Suçta Bankanın TMSF'ye Devredilmiş Ya Da Faaliyet İzninin Kaldırılmış Olması Koşulunun Niteliği, s.30; Donay, s.116; Yasemin Baba, "5411 Sayılı Bankacılık Kanununda Düzenlenen Zimmet Suçu Bağlamında Etkin Pişmanlık Uygulaması” s.254.

59 Sözüer, s.183.

60 Sözüer, s.182.

${ }_{61}$ Selçuk, s.232.

62 Selçuk, s.210. 
oldukları miktarı "zimmete geçirmiş gibi" sorumlu tutulmaları, suçun kast unsuru yönünden eleştirilmekteydi ${ }^{63}$. Fon'a devredilmemiş veya faaliyet izni kaldırılmamış bankalar açısından alınan kredilerin geri ödenmemesi sadece faaliyet zararı olarak kalacakken bankanın Fon'a devredilmesi veya faaliyet izninin kaldırılması halinde zimmet suçu kabul edilmesi de eleştiri konusuydu ${ }^{64}$. Gerçekten bankacılıkta yapılan en yaygın işlem kredi sözleşmeleri yoluyla kredi kullandırılmasıdır. Bankalar müşterileriyle yapacakları sözleşmelerle müşterisine belli bir oranda kredi sağlamayı, müşteri ise vadesi geldiğinde bu parayı faiziyle birlikte geri ödemeyi taahhüt etmektedir ${ }^{65}$. Bankaların, söz konusu ticari faaliyeti icra ederken üstlenmiş olduğu risk, kredinin geri dönmemesidir ${ }^{66}$. Bankanın kredileri kendi hâkim ortaklarına veya onun grup şirketlerine sağlaması halinde varsayımsal zimmet suçunun oluşup oluşmayacağ 1 değerlendirilmelidir. Bu konuda en önemli kıstas, failin kredinin geri dönmeyeceğini bilmesine rağmen kredi vermesi, kredinin verildiği anda bankacılık kurallarına uygun şekilde tahsis edilip edilmediğidir ${ }^{67}$. Kredinin alınmasıyla ilgili gerekli usuli işlemlere uyulması, kredi alanın mali yeterliliğinin bulunması, gerekli risk analizinin yapılması ve teminat alınması durumunda zimmet suçu oluşmaz ${ }^{68}$. Yargıtay da bir kararında teminatın varlığı halinde suçun oluşmayacağını kabul etmektedir ${ }^{69}$. Nitekim bu düşünceler doğrultusunda 01/02/2018 tarihli 7076 say1lı Kanun ile de aynen kabul edilen 687 sayılı Kanun Hükmünde Kararname ile 160. maddeye eklenen 4.fikrada "Bankacılık mevzuatı ile bankacılık usul ve prensiplerine uygun kredi kullandırma, bu kredileri temdit etme veya ek kredi kullandırma, taksitlendirme, teminata bağlama yahut sair yöntemlerle yeniden yapılandırma işlemleri zimmet suçunu oluşturmaz." denilerek anılan hususlar tereddüte yer vermeyecek şekilde teyit edilmek istenmiştir. Bunun yanında 17/07/2019 tarihli Bankacılık Kanunu'na eklenen Geçici 32. madde ile banka, finans kuruluşu gibi kurumlarla kredi ilişkisine giren borçluların geri ödeme yükümlülüklerini yerine getirebilmelerine ve istihdama katkıda bulunmaya devam etmelerine imkân verilmesini sağlamak amacıyla, borçların yeniden yapılandırmaya tabi tutulabileceği kabul edilmiştir. Bunun için borçlunun yeniden yapılandırma sonucunda borçlarını geri ödeme kabiliyeti kazanacağına kanaat getirilmesi şarttır. Düzenlemenin son fikrasında ilgili madde uyarınca yapılacak teminat

63 Sözüer, s.183

64 Sözüer, s.183; Gürses, s.65.

65 Fatih Selami Mahmutoğlu, Ekonomik Suçlar Bağlamında Kredi Hukukundan Kaynaklanan Suç ve İdari Suçlar, s.101.

66 Yasemin Baba, "5411 Sayılı Bankacılık Kanununda Düzenlenen Zimmet Suçu Bağlamında Etkin Pişmanlık Uygulaması” s.257.

67 Sözüer, s.177.

68 Güneş Okuyucu Ergün, Türk Ceza Hukukunda Zimmet Suçu, (2008), s.183.

69 Yargitay Ceza Genel Kurulu, 2002/11-158, 2005/58, 31/05/2005, bkz: Sözüer, s.181. 
IIIIIIIIII!

azaltma, anapara ve diğer alacaklardan vazgeçilerek kayıttan düşme yahut benzer işlemlerle kredilerin yeniden yapılandırılmasının bankacılık zimmeti suçunu oluşturmayacağı belirtilmektedir.

Bankacılık mevzuatında banka hâkim ortaklarına kredi tahsis edilemeyeceğine yönelik bir düzenleme bulunmamaktadır. Bankanın hâkim ortağına belirlenen limiti aşan kredi tahsis etmesi ise bankanın mali durumuna ilişkin ciddi sonuçlar doğurabilecektir. Banka bu limit sorununu aşmak için doğrudan kredi vermek yerine karşılıklı kredi açma, inançlı işlem ya da kıyı bankacılığı gibi uygulamalar ile hâkim ortağına dolaylı şekilde kredi tahsis edebilir. Bu işlemlerle amaç, kredi sınırlamalarına ilişkin hükümlerini dolanmak suretiyle banka hâkim ortağının grup şirketlerine yasal sınırların üzerinde kredi temin edilmesinin yolunu açmaktır ${ }^{70}$. Karş1lıklı kredi usulünde iki banka, karş11ıklı olarak hâkim ortak ve grup şirketlerine eşit miktar ve şartlarda kredi vermekte, bu krediler birbirinin teminatı olarak kabul edilmektedir ${ }^{71}$. Karş1l1kl1 kredi yöntemiyle hayali veya mali gücü yerinde olmayan şirketlere, kendilerinin veya üçüncü kişilerin menfaatlerine kredi kullandırmışlarsa, zimmet suçu oluşacaktır $^{72}$. İnançlı işlemde ise bir banka, görünüşte başka bir bankaya kredi açmasına rağmen krediyi alan banka aldığı krediyi, kredi aldığı bankanın grup şirketlerine vermektedir. İnançlı işlemlerle baştan itibaren geri ödemeyeceği bilinen veya mali yapısı itibarıyla kredi borcunu ödeme olanağ bulunmayan kişilere, gerekli teminatlar alınmaksızın kredi verilmesi halinde zimmet suçu oluşacaktır ${ }^{73}$. Kıyı bankacılığı ise bankacılık işlemlerinin bazı kolaylıklar gösterilmesi suretiyle yabanc1 ülkelerde gerçekleştirilmesidir. Yurt içindeki banka sadece aracı konumunda bulunmakta ve toplanan parayı yurt dışındaki bankaya aktarmaktadır ${ }^{74}$. Uygulamada Türkiye'de kurulu bankalar tarafindan, kendi bankasının kardeşi niteliğinde bir kıyı bankası ile muhabirlik sözleşmesi imzalanması ve Türkiye'de toplanan mevduatların, yurt dışında kurulu kıyı bankasına kağıt üzerinde havale edilmiş gibi gösterilmesi mümkündür ${ }^{75}$. Varsayımsal zimmet suçuyla bu gibi hileli kredi işlemleri yoluyla banka hâkim ortağının menfaat temin etmesi cezalandırılmak istenmiştir.

70 Ahmet Gökçen, "Bankalar Kanunu'nda Düzenlenen Zimmet Suçu (4387 s.l1 K. m. 22/34)”, (2005) 1 (S.10), Legal Malî Hukuk Dergisi 2665, s.2686.

71 Fatih Selami Mahmutoğlu, "Bankalar Kanununun Bankalar Kanununun 22/3 İle 22/4 Maddeleri Arasındaki Temel Farklar”, (2005) (S.3), Hukuki Perspektifler Dergisi 223, s.225.

72 Mehmet Emin Artuk, Ahmet Gökçen, Ahmet Caner Yenidünya, Ceza Hukuku Özel Hükümler, s.569; Asuman İnceoğlu Aytekin, s.390.

73 Sözüer, s.179; İnceoğlu Aytekin, s.391.

74 Dursun Selman, "Kı11 (Off-Shore) Bankacılı̆̆ı ve Ceza Hukuku Sorunları", (2004) Prof. Dr. Çetin Özek Armağanı, Galatasaray Üniversitesi Yayınları 32 247, s.260; Yasemin Baba, "5411 Sayılı Bankacılık Kanununda Düzenlenen Zimmet Suçu Bağlamında Etkin Pişmanlık Uygulamas1" s.259.

75 Aytekin İnceoğlu, s.141. 


\section{Bankacılık Kanunu 160/3. Maddesi Açısından Faaliyet İznini Kaldırılması veya Fon'a Devrin Cezalandırılabilme Şartı Olup Olmadığının Değerlendirilmesi}

Bankacılık Kanunu'nun 160/3. maddesinde gerçek kişi ortağın cezalandırılabilmesi, bankanın faaliyet izninin kaldırılmış veya Fon'a devredilmiş olmasına bağlanmıştır. İlgili şartın suçun maddi unsurlarına mı dâhil olduğu yoksa cezalandırılabilme şartı mı olduğu tartışmalıdır.

Bankanın faaliyet izninin kaldırılması veya Fon'a devredilme halleri Bankacıl1k Kanunu'nun 71. maddesinde düzenlenmiştir. İlgili maddede "Denetlemeler sonucunda bir bankayla ilgili olarak; a) Bu Kanunun 70 inci maddesi kapsamında alınmast istenen tedbirlerin Kurul tarafindan verilen süre içerisinde ya da her halükârda en geç oniki ay içinde kısmen ya da tamamen alınmaması ya da bu tedbirleri kısmen veya tamamen almış olmasına rağmen, malî bünyesinin güçlendirilmesine imkân bulunmadı̆̆ veya bu tedbirler alınmış olsa dahi malî bünyesinin güçlendirilemeyeceğinin tespit edilmesi, b) Faaliyetine devamının mevduat ve katılım fonu sahiplerinin haklart ve malî sistemin güven ve istikrar bakımından tehlike arz ettiğinin ortaya çıması, c) Yükümlülüklerini vadesinde yerine getiremediğinin tespit edilmesi, d) Yükümlülüklerinin toplam değerinin varlıklarının toplam değerini aşması, e) Hâkim ortaklarının veya yöneticilerinin, banka kaynaklarını, bankanın emin bir şekilde çalışmasını tehlikeye düşürecek biçimde doğrudan veya dolaylı veya dolanlı olarak kendi lehlerine kullanması veya dolanlı olarak kaynak kullandırması ve bankayı bu suretle zarara uğratması, Hâllerinden bir veya birkaçının varlığı durumunda Kurul, en az beş üyesinin aynı yöndeki oyuyla alınan kararla bankanın faaliyet iznini kaldırmaya ya da kredi kuruluşunun temettü hariç ortaklık hakları ile yönetim ve denetimini, zararın mevcut ortakların sermayesinden indirilmesi kaydıyla kısmen veya tamamen devri, satışı veya birleştirilmesi amacıyla Fona devretmeye yetkilidir.” denilmektedir. Öncelikle belirtmek gerekir ki suçun oluşumu için faaliyet izninin kaldırılması veya Fon'a devir şartının öngörülmesi, Bankacılık Düzenleme ve Denetleme Kurulu'na bu konularda geniş takdir yetkisinin tanınması, uygulamaya sübjektiflik karıştırabileceği ve suç ile cezada kanunilik ilkesine aykırı olduğu düşüncesiyle eleştiriye açıktır ${ }^{76}$.

Objektif cezalandırılabilme şartları, suçun unsurlarının dışında kalan, failin cezalandırılması için Kanun'un $\operatorname{aradığ} 1$ şartlardır ${ }^{77}$. Suçun kanuni tanımındaki hareket ve netice dışında suçun oluşumu için öngörülmüş diğer şartların objektif cezalandırılabilme şartı olması mümkündür ${ }^{78}$. Objektif

76 Sözüer, s. 183; Gürses, s.166; Yasemin Baba, “5411 Sayılı Bankacılık Kanununda Düzenlenen Zimmet Suçu Bağlamında Etkin Pişmanlık Uygulaması” s.262.

77 Hakeri, s.262.

78 Mehmet Emin Artuk, Mehmet Emin Alşahin, “Objektif Cezalandırılabilme Şartı ve 
IIIIIIIIII

cezalandırılabilme şartına yönelik failin kastının olup olmaması önemli değildir $^{79}$. Bir başka deyişle failin objektif cezalandırılabilme şartının varlığını bilip bilmemesi suçun oluşumuna etki etmez ${ }^{80}$. Bir görüşe göre bankanın Fon'a intikali, failin iradesinden bağımsız olarak Bankacılık Düzenleme ve Denetleme Kurulu tarafindan alınacak bir kararla olacağ 1 için suçun oluşumu açısından bu koşul objektif cezalandırılabilme şartıdır ${ }^{81}$. Bize göre de bankanın Fon'a intikali, failin fiilinin dışında, ondan bağımsız olarak gelişen bir durum olduğundan objektif cezalandırılabilme şartı olarak kabul edilmesi daha doğru olacaktır. Diğer görüsse göre ise cezalandırılabilme şartı, suçun oluşması için değil devletin cezalandırabilme yetkisini kullanabilmesinin fiilin dışında kalan bir olaya bağlanmasıdır. Faaliyet izninin kaldırılması veya Fon'a devir, suç konusu fiile yabancı bir unsur olmadığından cezalandırılabilme şartı olarak görülemez ve suçun maddi unsurlarına dâhildir ${ }^{82}$. Bu şartın objektif cezalandırılabilme şartı mı olduğu yoksa suçun unsurlarına mı dâhil bulunduğu hususu açılacak ceza davasında verilecek hüküm konusunda fark yaratmaktadır. Objektif cezalandırılabilme şartı suçun oluşmasını etkilememekte, sadece failin cezalandırılmamasını sağlamaktadır. Yani fiil hukuk düzeninde suç oluşturmaya devam ettirmektedir. Bu yüzden mahkeme, beraat kararı yerine CMK'nın 223/4. maddesi gereği ceza verilmesine yer olmadığına karar vermelidir $^{83}$. Bu hususun en önemli sonucu da, fiil, hukuk düzeninde hukuka aykırı olarak görülmeye devam ettiğinden failin özel hukuk sorumluluğu varlığını koruyacaktır. İlgili şartın suçun maddi unsurlarına ait olduğunun kabul edilmesi halinde verilecek karar ise suçun unsurları oluşmadığından beraat kararıdır. Beraat kararıyla fiil hukuk düzeni açısından da hukuka uygun kabul edileceğinden failin özel hukuk sorumluluğu da doğmayacaktır.

\section{E. Suçun Nitelikli Halleri}

\section{Ağırlaştırıcı Neden}

Bankacılık Kanunu'nun 160/2. maddesinde "Suçun, zimmetin açı̆̆a çıkmamasını sağlamaya yönelik hileli davranışlarla işlenmesi hâlinde faile on iki yıldan az olmamak üzere hapis ve yirmibin güne kadar adli para cezası

Zamanaşımı”, (2013) 19 (S.3), Marmara Üniversitesi Hukuk Fakültesi Hukuk Araştırmaları Dergisi 17, s. 19.

79 Hakeri, s.262.

80 Selçuk, s.236.

81 Sözüer, s.183; İnceoğlu Aytekin, s.142; Güngör, s.28; Fatih Selami Mahmutoğlu, Bankalar Kanununun 22/3 İle 22/4 Maddeleri Arasındaki Temel Farklar, s.232; Gökcan, s.447.

82 Güneş Okuyucu Ergün, Bankacılık Kanunu'nda Düzenlenen Zimmet Benzeri Suçta Bankanın TMSF'ye Devredilmiş Ya Da Faaliyet İzninin Kaldırılmış Olması Koşulunun Niteliği, s.36 vd; Uğur Yiğit, Bankacılık Suçları, (2006), s.457.

83 Mehmet Emin Artuk, Mehmet Emin Alşahin, "Objektif Cezalandırılabilme Şartı ve Zamanaşımı", s.47. 
verilir." denilmektedir. İlgili düzenleme 160/1. maddede düzenlenen basit zimmet suçunun nitelikli hali olarak kabul edilmektedir. Bir davranışın hile olarak nitelendirilebilmesi için sonucu gerçekleştirmeye elverişli, yoğun ve aldatıc1 nitelikte olmas1 gerekmektedir ${ }^{84}$. Yargitay'a göre “....zimmetin normal denetim ve bankada mevcut kaylt ve belgelerin karşılaştırılmasl ve kontrolü sonucu tespit edilip edilemeyeceği, suçun banka dlşı araştırmayl gerektirecek derecede bankayı aldatıcı ve fiilin açığa çıkmasını engelleyecek her türlü hileli faaliyette bulunmak suretiyle işlenip işlenmediğine..." bakılmalıdır ${ }^{85}$.

\section{Daha Az Cezayı Gerektiren Haller}

\section{a. Kullanma Zimmeti}

Kullanma zimmetine ilişkin esas düzenleme Türk Ceza Kanunu'nun 247/3. maddesinde yer almaktadır. Buna göre zimmet suçunun, malın geçici bir süre kullanıldıktan sonra iade edilmek üzere işlenmesi halinde, verilecek ceza yarı oranında indirilebilir. Yargıtay'a göre de görevi gereği kendisine tevdi edilen bir parayı belli süre kullanıp herhangi bir uyarı veya ihbar olmadan sanığın kendiliğinden yatırması halinde kullanma zimmeti söz konusu olacaktır ${ }^{86}$. Bankacılık Kanunu'nda kullanma zimmetine ilişkin bir düzenleme yer almamaktadır. Doktrinde bankacılık zimmetinde de kullanma zimmetinin uygulanabileceğini belirtilmektedir ${ }^{87}$. Yargıtay ise Bankacılık Kanunu'nda açıkça kullanma zimmetine yönelik bir düzenleme bulunmadığı için bankacılık zimmeti suçunda bu kurumun uygulanamayacağını kabul etmektedir ${ }^{88}$.

\section{b. Değer Azlı̆̆ı}

Bankac1l1k Kanunu'nun 160/7. maddesinde "Zimmet suçunun konusunu oluşturan para veya para yerine geçen evrak veya senetlerin veya diğer malların değerinin azlığı nedeniyle, verilecek ceza üçte birden yarıya kadar indirilir." hükmüne yer verilmiştir. Değer azlığının belirlenmesinde suç tarihindeki ekonomik koşullar ve paranın satın alma gücü gibi unsurlar esas alınmaktadır ${ }^{89}$. İndirim oranı da azlığın derecesine göre Kanun'da belirtilen alt ve üst sınırlar göz önüne alınarak mahkeme tarafından takdir edilecektir ${ }^{90}$.

84 Erdal Baytemir, Kamu İdaresinin Güvenilirliğine ve İşleyişine Karşı Suçlar ile Banka Zimmeti, (2011), s.47.

85 Yargitay 7.Ceza Dairesi, 2003/5543, 2004/4973, 08/04/2004, bkz: Güngör, s.26.

86 Yargitay 5. Ceza Dairesi, 2740/5909, 29/05/2014, < www.uyap.gov.tr. > (Erişim Tarihi: 23/12/2020).

87 Yargıtay 5. Ceza Dairesi, 84/1425, 14/04/1999, bkz: Selçuk, s.172; Aynı yönde bkz: İzzet Özgenç, Zimmet Suçu, s.128.

88 Yargitay 7. Ceza Dairesi, 2012/28265, 2013/15410, 28/05/2013, < www.uyap.gov.tr. > (Erişim Tarihi: 29/10/2021).

89 Yargitay 5. Ceza Dairesi, 2012/6741, 2013/4601, 06/05/2013, < www.uyap.gov.tr.> (Erişim Tarihi: 24/12/2020).

90 Y1lmaz, Öncel, Şahin, s.105. 
IIIIIIIIIII

\section{SUÇUN MANEVİ UNSURU}

Bankacılık zimmeti suçu kasten işlenebilen bir suçtur. Doktrinde suçun oluşması için kastın varlığı gerekli görülmektedir ${ }^{91}$. Suçun oluşabilmesi için failin zimmete geçirme, faydalanma, mal edinme gibi bir özel kastının bulunması gerektiği kabul edilmektedir ${ }^{92}$. Yargıtay'a göre de suçun oluşumu için özel kast niteliğindeki mal edinme, zimmete geçirme kastının varlığ 1 gereklidir $^{93}$.

\section{SUÇUN ÖZEL GÖRÜNÜŞ ŞEKİLLERİ}

\section{A. Teşebbüs}

Bankacılık zimmeti suçu, suç konusu üzerinde failin malik sıfatıyla hareket etmesiyle tamamlanacaktır ${ }^{94}$. Suçun gerçekleşmesi için neticenin ortaya çıkması şartı aranmadığından sırf hareket suçu olarak tanımlanmaktadır ${ }^{95}$. Hareketin bölünebildiği durumlarda suça teşebbüsün gündeme gelebileceğini kabul eden bir görüş de mevcuttur ${ }^{96}$. Varsayımsal zimmet suçu açısından ise yukarıda anlatıldığı şekilde objektif cezalandırılabilme şartının varlığı kabul edilirse suça teşebbüs mümkün olmayacaktır ancak objektif cezalandırılabilme şartı gerçekleştikten sonra, yani banka Fon'a devredildikten veya faaliyet izni kaldırıldıktan sonra suça teşebbüs mümkün hale gelecektir ${ }^{97}$. Bize göre de kural olarak bankacılık zimmeti suçu sırf hareket suçu olarak kabul edilse de failin icra hareketlerinin bölünebilmesi durumunda suça teşebbüs mümkün olacaktır. Bu sebeple her somut olay açısından değerlendirme yapılarak icra hareketlerinin bölünüp bölünmediğini tespit etmek gereklidir.

\section{B. Fikri İçtima}

Bankacılık Kanunu'nun 161. maddesinde özel bir içtima hükmüne yer verilmiştir. İlgili maddeye göre “Bu Kanun'a göre suç teşkil eden hareket ve fiiller başka kanunlara göre de cezayı gerektirdiği takdirde, failleri hakkında en ăgır cezayı gerektiren kanun maddesi uygulanır.”. Bankacılık Kanunu'ndaki hüküm, Bankacılık Kanunu'na göre suç teşkil eden hareket ve fiillerin başka kanunlara göre de cezayı gerektirmesi durumunu fikri içtima kapsamına

91 Aytekin İnceoğlu, s.396; Yılmaz, Öncel, Şahin, s.69.

92 Fatih Mehmet Mahmutoğlu, Ekonomik Suçlar Bağlamında Kredi Hukukundan Kaynaklanan Suç ve İdari Suçlar, s.258; Mehmet Emin Artuk/ Ahmet Gökcen/ Ahmet Caner Yenidünya, Ceza Hukuku Özel Hükümler, s.547; Donay, s.114.

93 Yargitay 7.Ceza Dairesi, 12968/17182, 23/12/2010; Yargitay 7.Ceza Dairesi, 1111/2031, 16/02/2010, bkz: Yılmaz, Öncel, Şahin, s.69.

94 Aytekin İnceoğlu, s.403.

95 Selçuk, s.174; Güngör, s.25; Erişen, s.114.

96 Mehmet Emin Artuk, Ahmet Gökçen, Ahmet Caner Yenidünya, Ceza Hukuku Özel Hükümler 2018, s.806.

97 Aytekin İnceoğlu, s.403. 
almışıุ'ı $^{98}$. Söz konusu madde ile işlenen fiilin Bankacılık Kanunu dışındaki başka bir kanuna göre de suç oluşturması halinde özel norm-genel norm ilişkisi yapılmayarak en ağır cezayı gerektiren kanun maddesinin uygulanması istenilmiştir99. Örnek olarak, Bankacılık Kanunu'nun 160/1. maddesindeki zimmet suçu için 6 yıldan 12 yıla kadar hapis cezası öngörülmesi karşısında Türk Ceza Kanunu'nun 247. maddesinde 5 y1ldan 12 yıla kadar hapis cezas1 öngörüldüğü için Bankacılık Kanunu'nun 161. maddesine göre daha ağır cezay1 gerektiren Bankacılık Kanunu'nun 160/1. madde hükmünün uygulanması gerekecektirr $^{100}$. Bir görüşe göre ise bu durumda fikri içtima hükümlerinin uygulanması söz konusu olmaz. Fikri içtima hükümlerinin uygulanabilmesi için tek bir eylem ile farklı suçların işlenmesi gereklidir. Dolayısıyla aynı suç bütün unsurlarıly hem genel hem özel kanunda düzenlenmiş ise fikri içtima hükümleri uygulanmayacak ve görünüşte içtima bulunduğundan özel nitelikteki kanun olaya uygulanacaktır ${ }^{101}$. Bankacılık zimmeti suçunu oluşturan bir fiil aynı zamanda Türk Ceza Kanunu'nda veya farklı bir kanundaki ayrı bir suça vücut veriyorsa Bankacılık Kanunu'nun 161. maddesi ancak bu durumda uygulanabilecek ve en ağır cezayı gerektiren hüküm faile tatbik edilecektir ${ }^{102}$.

Bankacılık zimmeti suçunun nitelikli halinin resmi veya özel belgede sahtecilik suçuyla birlikte işlenmesi halinde faile ayrıca Türk Ceza Kanunu'nun 204 veya 207. maddelerine göre de ceza verilip verilemeyeceği tartışmalıdır. Bir görüşe göre bu durumda Bankacılık Kanunu'nun 161. maddesi uyarınca faile yalnızca nitelikli zimmet suçundan ceza verilmesi gerekir ${ }^{103}$. Bizim de katıldığımız diğer bir görüşe göre ise Türk Ceza Kanunu'nun 212. maddesindeki resmi ve özel belgede sahtecilik suçlarıyla birlikte başka bir suçun birlikte işlenmesi halinde hem sahtecilikten hem de ilgili suçtan ceza verilmesini öngören hüküm karşısında failin iki suçtan da cezalandırılması gerekir ${ }^{104}$. Yargıtay'a göre ise Türk Ceza Kanunu'nun 212. maddesindeki düzenleme yalnızca Türk Ceza Kanunu'nda yer alan suçlar açısından uygulanabilecek bir kural niteliğindedir. Özel yasalarda düzenlenen suçlarla birlikte evrakta sahtecilik suçlarından ayrıca ceza verilebilmesi için bu konuda özel yasalarda açık düzenleme olmalıdır ${ }^{105}$.

\footnotetext{
Gürses, s.83.

Selçuk, s.182.

Aytekin İnceoğlu, s.406; Selçuk, s.183; Y1lmaz, Öncel, Şahin, s.77

101 Kayıhan İçel/ Hakan Evik, "Ceza Hukuku Genel Hükümler 2. Kitap, (2007), s.296; Gürses, s.83.

102 Gürses, s.83.

103 Gürses, s.84.

104 Mehmet Emin Artuk, Ahmet Gökçen, Ahmet Caner Yenidünya, Ceza Hukuku Özel Hükümler 2018, s.806.

105 Yargitay Ceza Genel Kurulu, 7-38/79, 06/04/2010, bkz: Y1lmaz, Öncel, Şahin, s.78 vd.
} 
IIIIIIIIIII-

\section{C. İştirak}

Bankacılık zimmeti suçu yalnızca banka mensupları veya gerçek kişi ortaklar tarafından işlenebildiği için özgü suç niteliğindedir ${ }^{106}$. Yargıtay uygulamasında da bankacılık zimmeti suçu özgü suç olarak değerlendirilmiş ve Bankacılık Kanunu'nda belirtilen niteliği taşımayan kişilerin suçun faili olamayacağ kabul edilmiştir ${ }^{107}$. Türk Ceza Kanunu'nun 40/2. maddesinde belirtildiği şekilde "Özgü suçlarda, ancak özel faillik niteliğini taşıyan kişi fail olabilir. $\mathrm{Bu}$ suçların işlenişine iştirak eden diğer kişiler ise azmettiren veya yardım eden olarak sorumlu tutulur." hükmüyle özgü suçlara iştirak eden kişiler ancak azmettiren veya yardım eden olarak sorumlu tutulabileceklerdir. Suçun, görevi gereği zilyetliği kendisine teslim edilmiş veya koruma ve gözetim yükümlülüğü bulunan mallara karşı görevli birden fazla banka mensubu tarafından işlenmesi halinde her fail Türk Ceza Kanunu'nun 37. maddesine göre sorumlu olacaktır. Banka mensubu olmayan ya da görevi gereği mala zilyet olmayıp koruma ve gözetim yükümlülüğü de bulunmayan banka mensubu ise ancak fiilin niteliğine göre yardım eden ya da azmettiren olarak sorumlu tutulacaktır ${ }^{108}$.

Varsayımsal zimmet suçuna ilişkin doktrindeki bir görüşe göre Fon'a intikal eden bankada ortak olmayan kişi, yönetim kurulu üyeleri ve diğer banka görevlileri bu suçun faili olamaz. Çünkü bu suçun faili olarak gerçek kişi ortaklar gösterilmiştir. $\mathrm{Bu}$ sebeple yönetim kurulu üyelerinin ve diğer yöneticilerin fiilleri ancak yardım eden veya azmettiren olarak nitelendirilebilir ${ }^{109}$. Diğer görüşe göre ise yönetim kurulu üyelerinin bu suçun faili olmalarının önünde bir engel bulunmamaktadır. Bu sebeple Türk Ceza Kanunu'nun 37. maddesine göre fail olarak sorumlu tutulabilirler ${ }^{110}$. Bize göre ilgili maddede açıkça ancak gerçek kişi ortakların suçun faili olabileceği belirtildiği için yönetim kurulu üyeleri ile diğer yöneticiler fail olarak cezalandırılamaz.

\section{SORUŞTURMA VE KOVUŞTURMA USULÜ}

Bankacılık Kanunu'nun 162. maddesinde Bankacılık Kanunu'nda yer alan suçlara ilişkin soruşturma ve kovuşturma yapılmasının BDDK veya TMSF tarafından Cumhuriyet Başsavcılığı'na yazılı başvuruda bulunulması şartına bağlı olacağ 1 belirtilmiştir. $\mathrm{Bu}$ başvuru muhakeme şartı niteliğindedir ${ }^{111}$.

106 Sözüer, s.176; Aytekin İnceoğlu, s.215; Selçuk, s.246.

107 Yargitay 7.Ceza Dairesi, 17090/3625, 26/04/2017, < www.uyap.gov.tr.> (Erişim Tarihi: 22/12/2020).

108 Yargitay 7.Ceza Dairesi, 10566/13284, 16/05/2012, < www.uyap.gov.tr.> (Erişim Tarihi: 22/12/2020).

109 Sözüer, s.184; Güneş Okuyucu Ergün, Türk Ceza Hukukunda Zimmet Suçu, s.32.

110 Aytekin İnceoğlu, s.404.

111 Yargıtay 7. Ceza Dairesi, 13741/9824, 22/05/2014, < www.uyap.gov.tr.> (Erişim Tarihi: 01/01/2021). 
Muhakeme şartları gerçekleşmediği sürece yargılamanın başlatılması, devam ettirilmesi ve sonuçlandırması mümkün değildir ${ }^{112}$. Gerçekten CMK'nın 223/8. maddesine göre Türk Ceza Kanunu'nda öngörülen düşme sebeplerinin varlığı ya da soruşturma veya kovuşturma şartının gerçekleşmeyeceğinin anlaşılması hallerinde, davanın düşmesine karar verilir. Ancak, soruşturmanın veya kovuşturmanın yapılması şarta bağlı tutulmuş olup da şartın henüz gerçekleşmediği anlaşılırsa; gerçekleşmesini beklemek üzere, durma kararı verilir.

Söz konusu yazılı başvurunun niteliği doktrinde tartışmalıdır. TMSF veya BDDK'nın suçtan doğrudan zarar gören niteliğinde olmaması ve yazılı başvurunun bir süreye bağlanmaması, yapılan başvurunun şikâyet niteliğinde olmadığını göstermektedir ${ }^{113}$. İlgili kurumlar tarafindan yapılan yazılı başvurunun talebe benzediğ $1^{114}$ ifade edilmekteyse de talep sonucu Cumhuriyet savcısının kamu davası açma zorunluluğunun bulunmaması, yazılı başvurunun talep mahiyetinde de olmadığını göstermektedir ${ }^{115}$. Bizim de katıldığımız başka bir görüşe göre bankacılık zimmeti suçunda ilgili kurumun dava açılmasını zorunlu kılmayacak şekilde yaptığı başvuru, müracaat niteliğindedir ${ }^{116}$. Müracaatın mülga Türk Ceza Kanunu dönemine ait bir kurum olduğunu ve yeni ceza hukuku sistemimize göre geçmişte müracaat olarak kabul edilen başvuruların artık şikâyet olarak kabul edilmesi gerektiğini, kanun koyucunun ise yazılı başvuruları açıç̧a şikâyet olarak adlandırmadığını belirterek yazılı başvurunun "sui generis" bir niteliği bulunduğunu kabul eden bir görüş de mevcuttur ${ }^{117}$.

Yargıtay, bankanın da bu madde kapsamında yazılı başvuruda bulunabileceğini, banka veya BDDK'nın yazılı başvurusunun muhakeme şartı için yeterli olduğunu kabul etmektedir ${ }^{118}$. Soruşturma ve kovuşturma kural olarak yazılı başvuru şartına bağlanmış ise de varsayımsal zimmet suçuna ilişkin bir istisnaya yer verilmiştir. Buna göre 160. maddenin üçüncü fikrasında belirtilen suçtan dolayı soruşturma ve kovuşturmalar Kurum'un veya Fon'un yazılı bildirimi üzerine veya gecikmesinde sakınca görülen

112 Hakeri, 99.

113 Selçuk, s.263; Uygun, s.156.

114 Güngör, s.28.

115 Feridun Yenisey, Ayşe Nuhoğlu, ““'Yazılı Başvuru” Şartının Hukuki Niteliği”" (2013), (S.101), Kazancı Hukuk Araştırmaları Dergisi, s.102; Ahmet Mücahit Selçuk, "5411 Sayılı Bankacılık Kanununda Düzenlenen Zimmet Suçları”, s.263; Gürses, s.107.

116 Güneş Okuyucu Ergün, Türk Ceza Hukukunda Zimmet Suçu, s.196; Selman Dursun, Yeni Bankacılık Kanunu'nda Yer Alan Ceza Muhakemesi ve İnfaz Hükümleri, (Say1:4), (2007), Ceza Hukuku Dergisi, s.264.

117 Gürses, s.107.

118 Yargitay 7. Ceza Dairesi, 189719268, 07/06/2012, < www.uyap.gov.tr.> (Erişim Tarihi: 01/01/2021). 
IIIIIIIIII

hallerde re'sen Cumhuriyet savcılarınca yapilır ve Kurum ile Fon haberdar edilir. Yapılan soruşturmalar neticesinde açılan kamu davalarında, Kurum'un veya Fon'un başvuruda bulunması hâlinde, bunlar başvuru tarihinde müdahil sıfatını kazanırlar. Bankacılık Kanunu'nun 163. maddesine göre başlatılan soruşturma neticesinde kovuşturmaya yer olmadığına karar verilmesi halinde bu karar, ilgilisine göre BDDK veya TMSF'ye tebliğ edilecektir. Tebliğ işlemi yapılan kurumun Ceza Muhakemesi Kanunu uyarınca bu karara itiraz hakkı bulunmaktadır. Varsayımsal zimmet suçunda soruşturma bizzat Cumhuriyet Başsavcısı veya görevlendireceği Cumhuriyet savcısı tarafindan yapılacaktır. Bankacılık Kanunu'nun 166. maddesine göre Cumhuriyet Başsavcılıkları, bu suçların soruşturmasında gerekli olması hâlinde, geçici olarak yargı çevresi içerisindeki veya dışındaki, genel bütçeli dairelere ve katma bütçeli idarelere, bütün kamu kurum ve kuruluşlarına, belediyelere, bankalara ait bina, araç, gereç ve personelden yararlanmak için istemde bulunabilirler. $\mathrm{Bu}$ istemler, ilgili kurum ve makamlarca geciktirilmeksizin yerine getirilir. Özürsüz olarak bu istemleri yerine getirmeyen sorumlu kişiler, üç aydan altı aya kadar hapis cezası ile cezalandırılır. Soruşturmanın gerekli kıldığı hâllerde, suç mahalli veya delillerin bulunduğu yerlere gidilerek soruşturma yapılır. Soruşturmanın sonuçlanmasına kadar, bu suç faillerinin her türlü mal, alacak, para ve sair eşyalarına hâkim kararı, gecikmesinde sakınca olunan hallerde Cumhuriyet savcısının yazılı emri ile el konulur. Bu suçlara iştirak edenler ile suç faillerinin bu suçlar nedeniyle elde ettiği her türlü haksız kazanımın transferi sonucu elde edilen, kan ve kayın hısımlar ile üçüncü şahıslar nezdindeki mal, alacak veya sair her türlü şeylere de Cumhuriyet savcısının yazılı emri ile el konulur. El koyma kararı yirmi dört saat içinde yetkili ve görevli sulh ceza hâkiminin onayına sunulur. Hâkim kırk sekiz saat içinde kararını açıklar. Aksi halde el koyma hükümsüz kalır.

Bankacılık zimmeti suçları açısından özel bir yetki hükmü bulunmaktadır. Bankacılık Kanunu'nun 164. maddesine göre bankacılık zimmeti suçuna ilişkin davalar, fiilin işlendiği yerin bağlı olduğu ilin adıyla anılan (1) numaralı Ağır Ceza Mahkemesi'nde görülmektedir. Bankacılık suçlarında bilirkişi incelemesi de özel olarak düzenlenmiştir. Bankacılık Kanunu'nun 165. maddesine göre açılan davalarda bilirkişinin raporunu hazırlaması için 3 aylık sürenin bulunduğu, hâkimin bu süreyi 2 ay daha uzatabileceği belirtilmiştir. Bilirkişinin raporunu süresinde hazırlamaması halinde dosyanın kendisinden alınacağı, ayrıca 1 yıl süreyle Bankacılık Kanunu kapsamındaki davalarda bilirkişi olarak yer alamayacağı belirtildiği gibi 500 güne kadar adli para cezasına mahkûm edilecekleri de kabul edilmektedir. Dosyanın bilirkişiye tevdi edilmesiyle dava zamanaşımı durmaktadır. Raporun teslim edilmesiyle bu süre kaldığı yerden işlemeye başlar. Bankacılık Kanunu'nun 167. maddesine göre bankacılık zimmeti suçundan mahkûm olanlar, Fon'a 
veya Hazine'ye olan borçları ve tazminatları ödemediği veya bu borçlar ve tazminatlar malvarlıklarından tahsil olunamadığı sürece, bunlar hakkında koşullu salıverilme hükümleri uygulanmaz.

Bankacılık Kanunu'nun Geçici 31. maddesi'nde Avrupa İnsan Hakları Mahkemesi'ne yapılmış başvurulara iç hukukta sonuç bağlanan bir düzenlemeye yer verilmiştir. Buna göre bankacılık mevzuatının uygulanmasıyla ilgili olarak, Avrupa İnsan Hakları Mahkemesi'ne yapılmış başvuru veya Avrupa İnsan Hakları Mahkemesi'nin kararı kapsamında karşılıklı olarak dostane çözüme ulaşı1ması hâlinde, ilgili kamu otoritesinin şikâyet ya da yazılı başvurudan vazgeçme veya müdahillikten çekilme beyanının ilgili Cumhuriyet savcılığ1 veya mahkemeye ulaşması üzerine, dostane çözüm kapsamına giren fiiller nedeniyle yapılmakta olan soruşturma veya kovuşturmada şüpheli veya sanıklar hakkında kovuşturmaya yer olmadığına veya davanın düşmesine verileceği kabul edilmektedir.

\section{YAPTIRIM}

Bankacılık zimmeti suçunun birinci fikrasındaki basit zimmet suçu için altı yıldan on iki yıla kadar hapis ve beş bin güne kadar adli para cezası öngörülmüştür. Ayrıca faillerin bankanın uğradığı zararı tazmine mahkûm edileceği de belirtilmiştir. Ceza mahkemesinin adli para cezasının yanında tazminata da hükmedecek olmasının hükümlünün ödemede önceliği adli para cezasına vereceği gerekçesiyle eleştirilmektedir ${ }^{119}$. Bankanın uğradığı zararın tazmininde ağır ceza mahkemesi, bir özel hukuk mahkemesi gibi davranarak zararı hesaplamalı ve hüküm kısmında bu zararı açıklamalıdır ${ }^{120}$. Yargıtay'a göre ceza mahkemesi, sadece bankanın zararını suç tarihindeki değere göre hesaplamalıdır ${ }^{121}$. Mahkemenin hükmedeceği tazminatın şahsi hakka ilişkin olduğu savunulmaktadır ${ }^{122}$. Tazminat miktarının belirlenmesi esas olarak hukuk mahkemelerinin görev alanına girmesine rağmen ilgili zararın tazminine ceza mahkemesinin hükmetmesi usul ekonomisi ilkesi ile açıklanmaktadır ${ }^{123}$. Her ne kadar usul ekonomisi ilkesi sebebiyle ceza mahkemesine tazminata hükmetme yetkisi tanınmışsa da ceza mahkemesinin zarardan kaynaklı faize hükmetmemesi bankanın veya zarara uğrayanların sonradan tekrar hukuk mahkemesinde dava açmasına neden olacaktır ${ }^{124}$.

\footnotetext{
Selçuk, s.183.

Aytekin İnceoğlu, s.408.

121 Yargitay 7. Ceza Dairesi, 2008/13185, 2011/18429, 02/11/2011, < www.uyap.gov.tr.> (Erişism Tarihi: 23/12/2020).

122 Aytekin İnceoğlu, s.408; Donay, s.110.

123 Gürses, s.98.

124 Selçuk, s.184.
} 
IIIIIIIIIII-

Bankacılık zimmeti suçunun ikinci fikrasına göre suçun hileli davranışlarla işlenmesi halinde faile on iki yıldan az olmamak üzere hapis ve yirmi bin güne kadar adli para cezası verilir; ancak, adli para cezasının miktarı bankanın uğradığı zararın üç katından az olamaz. Ayrıca meydana gelen zararın ödenmemesi hâlinde mahkemece re'sen ödettirilmesine hükmolunur.

Bankacılık zimmeti suçunun üçüncü fikrasındaki varsayımsal zimmet suçunda faile on yıldan yirmi yıla kadar hapis ve yirmi bin güne kadar adlî para cezasına hükmolunur; ancak, adlî para cezasının miktarı bankanın uğradığı zararın üç katından az olamaz. Ayrıca, meydana gelen zararın müteselsilen ödettirilmesine karar verilir.

\section{ETKIN PISŞMANLIK}

Zimmet suçu ile bir zarar oluşmuşsa bu zararın tazmini hem Türk Ceza Kanunu'nda hem de Bankacılık Kanunu'nda etkin pişmanlık hali olarak öngörülmüştür. Zararın tazmin anına göre failin cezasında etkin pişmanlık sebebiyle yapılacak indirim farkl11ık göstermektedir.

Banka malvarlığına karşı işlenen suçlarda zararın tespitinin uzun zaman alması, zarar tespit çalışmaları devam ederken soruşturma veya kovuşturma aşamasına geçilmesi halinde zararı karşılamak isteyen failin somut iradesi esas alınarak etkin pişmanlık anının failin ödemeye yönelik somut iradesinin ortaya çıktığ 1 an olarak belirlenmesi gerektiği ifade edilmektedir ${ }^{125}$. Bankacılık Kanunu'na göre soruşturma başlamadan önce, malın aynen iade edilmesi veya uğranılan zararın tamamen tazmin edilmesi hâlinde verilecek cezanın üçte ikisi, kovuşturma başlamadan önce, gönüllü olarak, malın aynen iade edilmesi veya uğranılan zararın tamamen tazmin edilmesi hâlinde ise verilecek cezanın yarısı indirilecektir. Bu durumların hükümden önce gerçekleşmesi hâlinde ise verilecek cezanın üçte biri indirilir. Söz konusu iadenin veya zarar tazmininin gönüllü olması gerekmektedir. Hukuk mahkemelerinde açılan bir davanın neticelenmesinin ardından, zararın icra yoluyla karşılanması halinde bu hüküm uygulanmayacaktır ${ }^{126}$. Etkin pişmanlıkta karşılanması gereken zarara faiz ve mahrumkalınan kârdâhil edilmeyecektir ${ }^{127}$. Suç konusu malın aynen iade edilmesi veya zararın tazminini kural olarak fail bizzat gerçekleştirmelidir. Üçüncü kişilerin bu zararı gidermesi halinde, failin suçtan pişmanlığı bulunuyorsa ve zararın tazminine yönelik bilgisi varsa, etkin pişmanlık hükümleri uygulanabilir. Gerçekten failin cezaevinde bulunduğu veya şahsen zararı gideremediği durumlarda failin yakını, tanıdığı veya ailesi aracılığıyla zararın giderilmesi gibi hallerde fail hakkında etkin pişmanlık hükümleri uygulanabilecektir.

125 Sözüer, s.186.

126 Aytekin İnceoğlu, s.401.

127 Y1lmaz, Öncel, Şahin, s.110. 
Bankacılık Kanunu'nda kovuşturma başlamadan önce failin gönüllü olarak zararı karşılaması gerektiği belirtilirken soruşturma başlamadan önce zararın giderilmesi halinde gönüllü olma koşulu aranmamıştır. Bir görüşe göre her iki durumda da failin etkin pişmanlığı gönüllü şekilde gerçekleştirmesi gerekmektedir ${ }^{128}$. Yargitay ise madde metninde açıkça soruşturma başlamadan önce gönüllü olma şartı aranmadığı gerekçesiyle gönüllülüğün gerekmediğini belirtmektedir ${ }^{129}$. Bize göre etkin pişmanlık kurumunun temelinde failin gönüllü şekilde zararı giderme düşüncesi yatmaktadır. Bu sebeple Bankacılık Kanunu'nda kovuşturma başlamadan önce etkin pişmanlığın gönüllü olması gerektiği belirtilirken soruşturmadan önce gönüllü olması gerektiğine yönelik ibarede bulunulmaması maddi hata olarak değerlendirilmelidir.

Etkin pişmanlık ile ilgili bir diğer husus, varsayımsal zimmet suçunda TMSF'ye devredilen bankalarda banka ana ortaklarının TMSF ile yapacakları anlaşmalar sonucu TMSF'ye yapacakları ödemelerin etkin pişmanlık olarak kabul edilip edilemeyeceğidir. Anlaşma uyarınca yapılan ödemeler için etkin pişmanlık hükümlerinin uygulanacağ 1 kabul ediliriro. Bir görüşe göre ise bu durumda etkin pişmanlığın uygulanabilmesi için anlaşmayla belirlenen zarar ile mahkemenin belirlediği zarar miktarının aynı olması ve zararın en geç hükümde önce tamamen ödenmiş olması gereklidir ${ }^{131}$.

\section{SONUÇ}

Bankacılık zimmeti suçunda korunan hukuki değer hem malikin mülkiyet hakkı hem de ülkedeki ekonomik düzenin işleyişine duyulan güvendir. Tüzel kişilerin suçun mağduru olamayacağı gözönüne alındığında bankacılık zimmeti suçlarında banka suçtan zarar gören konumundadır. Bankacılık zimmeti suçu özgü suçlardandır. Fail sadece banka mensubu olabilir. Banka mensubunun fail olabilmesi için bankayla arasında bir sözleşme ilişkisinin bulunması ve görev tanımının bankacılık faaliyetine ilişkin olması gereklidir.

Bankacılık zimmeti suçu, 5411 sayılı Bankacılık Kanunu'nun 160. maddesinde temel olarak iki ayrı suç olarak düzenlenmiştir. İlk fikrada düzenlenen bankacılık zimmetinin temel halinde fail, görevi gereği zilyetliği kendisine devredilmiş veya koruma ve gözetmekle yükümlü olduğu malı tahsis edildiği amaç dışında kendisi veya başkası için mal edinme kastıyla hareket etmektedir. Varsayımsal zimmet suçunda ise faaliyet izni kaldırılan veya Fon'a devredilen bir bankanın; hukuken veya fiilen yönetim ve denetimini elinde bulundurmuş olan gerçek kişi ortaklarının, kredi kuruluşunun kaynaklarını

\footnotetext{
128 Aytekin İnceoğlu, s.401.

129 Yargitay Ceza Genel Kurulu, 2011/7-429, 2012/181, 08/05/2012, bkz: Y1lmaz, Öncel, Şahin, s.111-112.

130 Sözüer, s.186.

131 Gürses, s.96.
} 
IIIIIIIIII

emin bir şekilde çalışmasını tehlikeye düşürecek şekilde doğrudan veya dolaylı olarak kendilerinin veya başkalarının menfaatlerine kullandırmak suretiyle, kredi kuruluşunu her ne suretle olursa olsun zarara uğratmaları zimmet olarak kabul edilmektedir. Lafzi ifadeyle de belirtildiği şekilde teknik anlamda zimmet tanımına uymayan bir eylem zimmet kabul edilerek cezalandırılmaktadır. Banka hâkim ortağına tahsis edilen kredinin ödenmemesi tek başına suçun oluşumuna sebebiyet vermez. Suçun oluşabilmesi için kredinin geri ödenemeyeceği bilinmesine rağmen kredinin verilmesi gereklidir. Bunun için kredi alanın mali yeterliliğinin olup olmadığı, gerekli risk analizinin yapılıp yapılmadığ 1 , teminat alınıp alınmadığ gibi hususlar birlikte değerlendirilerek failin suç kastının varlığı tespit edilmelidir. Varsayımsal zimmet suçunun oluşması için bankanın faaliyet izninin kaldırılması veya TMSF'ye devredilmesi gereklidir. $\mathrm{Bu}$ şart objektif cezalandırılabilme şartı niteliğindedir.

Bankacılık zimmeti suçunun işlenmesi halinde faile hapis ve adli para cezasının yanında bankanın uğradığı zararı tazmine mahkûm edilmektedir. Yargılama yapan ağır ceza mahkemesinin bir hukuk mahkemesi gibi davranarak oluşan zararı hesaplaması gereklidir. Bankacılık faaliyetlerinin uzmanlık gerektiren teknik ve karmaşı niteliği gereği zararın ve zimmet fiilinin tam olarak belirlenmesinin uzun süre alacağı göz önüne alındığında dava ile ilgili bilirkişi görevlendirmesi yapılması halinde zamanaşımı süresinin duracağı hüküm altına alınmıştır.

\section{KAYNAKÇA}

Akçin İ, Aslan V, Kamu İdaresinin Güvenilirliğine ve İşleyiş̧ine Karşı Suçlar (2.Bask1, Adalet Yayınevi, 2019).

Zimmet Suçu İstanbul Üniversitesi Hukuk Fakültesi Mecmuası (C.LXXI, S.1, 2013), s.43-66.

Artuk M.E ve Alşahin M. E, Objektif Cezalandırılabilme Şartı ve Zamanaşımı, Marmara Üniversitesi Hukuk Fakültesi Hukuk Araştırmaları Dergisi (C.19, S:3, 2013), s.17-44.

Artuk M.E, Gökçen A ve Yenidünya A.C, Ceza Hukuku Özel Hükümler (11. Bask1, Turhan Kitabevi, 2011).

Artuk M.E, Gökçen, A, Alşahin, M.E ve Çakır K, Ceza Hukuku Özel Hükümler (17.Bask1, Adalet Yayınevi, 2018).

Baba Y, 5411 Sayılı Bankacılık Kanununda Düzenlenen Zimmet Suçu Bağlamında Etkin Pişmanlık Uygulaması Türkiye Adalet Akademisi Dergisi (Y11 3, S.9, Nisan 2012), s.253-280. 
Baba, Y, Haksızlık İçeriğindeki Azlığın Cezalandırma Üzerindeki Etkisi İstanbul Üniversitesi Sosyal Bilimler Enstitüsü, Yayımlanmamış Doktora Tezi, İstanbul, 2017.

Baytemir E, Kamu İdaresinin Güvenilirliğine ve İşleyişine Karşı Suçlar ile Banka Zimmeti (Adalet Yayınevi, 2011).

Centel N, Zimmet Suçu(TCK 247) Dokuz Eylül Üniversitesi Hukuk Fakültesi Dergisi (Prof. Dr. Durmuş TEZCAN'a Armağan, C.21, Özel S., 2019), s. 2779-2800.

Donay S, Bankacılık Ceza Hukuku (Beta Yayıncılık, 2007).

Dursun S, Ekonomik Suçlar ve Bankacılık Suçları Bağlamında Bankacılık Düzenine Karşı İşlenen Suçlar (Seçkin Yayıncılık, 2006).

Dursun S, Kıyı (Off-Shore) Bankacıllğı ve Ceza Hukuku Sorunları Prof. Dr. Çetin Özek Armağanı, Galatasaray Üniversitesi Yayınları 32 (2004), s.247282.

Dursun S, Yeni Bankacılık Kanunu'nda Yer Alan Ceza Muhakemesi ve İnfaz Hükümleri, Ceza Hukuku Dergisi, (Sayı:4, 2007), s.263-275.

Erişen M, Bankacılık Zimmeti Sayıştay Dergisi (S.83, 2011), s.97-123.

Gülşen T, Zimmet Suçu Ankara Üniversitesi Sosyal Bilimler Enstitüsü, Yayımlanmamış Yüksek Lisans Tezi, Ankara, 2011.

Güngör D, 5411 Sayılı Bankacılık Kanununda Zimmet Suçu Ankara Barosu Dergisi (Y1l 67, S.4, 2009), s.23-29.

Gürses D, Bankacılık Kanunu'na Göre Zimmet Suçu (B.2, On İki Levha Yayincilik, 2009).

Gökçen A, Bankalar Kanunu'nda Düzenlenen Zimmet Suçu (4387 s.1ı K. m. 22/3-4), Legal Malî Hukuk Dergisi (C. 1, S. 10, Nisan 2005), s. 2665-2693.

Gökcan H.T, Güveni Kötüye Kullanma, Zimmet, Banka Zimmeti, İrtikap, Rüşvet Suçları ve Kamu İdaresi'ne Karşı İşlenen Suçlar (Seçkin Yayınları, 2008).

Hakeri H, Ceza Hukuku Genel Hükümler (24.Bask1, Adalet Yayınevi, 2021).

Haznedar İ.M, Bankacılık Zimmeti Suçu, Legal Hukuk Dergisi (Nisan 2007), s.1169-1188.

İçel K ve Evik H, Ceza Hukuku Genel Hükümler, 2. Kitap, (Beta Yayıncılık, 2007).

İnceoğlu Aytekin A, Bankacılık Kanunu'nda Yer Alan Suçlar Marmara Üniversitesi Sosyal Bilimler Enstitüsü, Yayımlanmamış Doktora Tezi, İstanbul, 2006. 
IIIIIIIIII!

Mahmutoğlu F, Bankalar Kanununun 22/3 İle 22/4 Maddeleri Arasındaki Temel Farklar Hukuki Perspektifler Dergisi (S.3, 2005), s.223-238.

Mahmutoğlu F, Ekonomik Suçlar Bağlamında Kredi Hukukundan Kaynaklanan Suç ve İdari Suçlar (Seçkin Yayınevi, 2003).

Malkoç İ, Yeni Türk Ceza Kanunu Uygulamasında Zimmet İrtikap Rüşvet Suçları (Malkoç Yayınevi, 2010).

Okuyucu Ergün G, Bankacılık Kanunu'nda Düzenlenen Zimmet Benzeri Suçta Bankanın TMSF’ye Devredilmiş Ya Da Faaliyet İzninin Kaldırılmış Olması Koşulunun Niteliği Terazi Hukuk Dergisi, (S.39, 2009), s.29-41.

Okuyucu Ergün G, Türk Ceza Hukukunda Zimmet Suçu (Çakmak Yayınevi, 2008).

Özgenç İ, Zimmet Suçu (Genişletilmiş 2.Bask1, Seçkin Yayınc1lık, 2012).

Özgenç İ, Türk Ceza Hukuku Gazi Şerhi (3.Baskı, Adalet Bakanlığı Eğitim Dairesi Başkanlığı, 2006).

Selçuk A.M, 5411 Sayılı Bankacılık Kanununda Düzenlenen Zimmet Suçları İstanbul Üniversitesi Sosyal Bilimler Enstitüsü, Yayımlanmamış Yüksek Lisans Tezi, İstanbul, 2019.

Sözüer A, Yeni Bankacılık Kanununda Suçlar ve Yaptırımlar Hukuki Perspektifler Dergisi, (S.5, 2005), s. 166-191.

Tekinalp Ü, Ünal Tekinalp'in Banka Hukuku'nun Esasları, (Yeniden Yazılmış 2.Bask1, Vedat Kitapç11ı, 2009).

Tiryaki G, Ekonomik Suçlar, Bankacılık Suçları ve Bu Tür Suçlarla Mücadele Stratejisi Active Bankac1lık ve Finans Dergisi, (Y11:6, S.34, Ocak - Şubat 2004), s.56-74.

Toroslu N, Ceza Hukuku Özel Kısım (Savaş Yayınevi, 2007).

Toroslu N, Ceza Hukuku (Savaş Yayınevi, 2005).

Tuğrul A.C, Öğreti ve Uygulamada Zimmet Banka Zimmeti Rüşvet ve İrtikâp Suçları (2.Baskı, Seçkin Yayıncılık, 2013).

Uygun Ç, Bankacılık Kanunu'nun 160'ıncı Maddesinde ve Türk Ceza Kanunu'nun 247'nci Maddelerinde Yer Alan Zimmet Suçu Yeditepe Üniversitesi Sosyal Bilimler Enstitüsü, Yayınlanmamış Yüksek Lisans Tezi, İstanbul, 2019. Yenisey F ve Nuhoğlu A, "Yazılı Başvuru» Şartının Hukuki Niteliği, Kazancı Hukuk Araştırmaları Dergisi, (S.101, 2013), s.97-108.

Yılmaz Ö, Öncel H ve Şahin Ü, Banka Zimmeti (Adalet Yayınevi, 2018). 
Yiğit U, Bankacılık Suçları, (Has Matbaacılık, 2006).

Yüksektepe M.A, TCK Genel Hükümleri Dâhilinde Bölge Adliye Mahkemeleri Ceza Daireleri ve Yargitay Kararları ile Zimmet (Aristo Yayınevi, 2018).

Yüksel A.S, Yüksel A, Yüksel Ü, Bankacıllk Hukuku ve İşletmesi (Beta Yayınc1lik, 2004).

\section{Elektronik Kaynaklar:}

https://www.mevzuat.gov.tr

https://normkararlarbilgibankasi.anayasa.gov.tr/

https://www.uyap.gov.tr 
Bankacılık Zimmeti Suçu

Onuralp ATAY, LL.M.

IIIIIIIIII! 